\title{
New toxodontid (Notoungulata) from the Early Miocene of Mendoza, Argentina
}

\author{
Analía M. Forasiepi • Esperanza Cerdeño • Mariano Bond · Gabriela I. Schmidt • \\ Maximiliano Naipauer · Fiona R. Straehl • Agustín G. Martinelli • \\ Alberto C. Garrido • Mark D. Schmitz · James L. Crowley
}

Received: 21 November 2013/Accepted: 12 May 2014/Published online: 18 June 2014

(C) Springer-Verlag Berlin Heidelberg 2014

\begin{abstract}
We describe a new toxodontid species, Nesodon taweretus sp. nov., from the Aisol Formation in Mendoza Province, central-west Argentina. Nesodon is a frequently found Toxodontidae, member of the Notoungulata, an extinct endemic group of Cenozoic South American mammals that are ecologically similar to current hoofed ungulates. The holotype of $N$. taweretus sp. nov. is a skull, and we tentatively assign some mandibular fragments and postcranial bones. $N$. taweretus sp. nov. differs from the other Nesodon species in several cranial and
\end{abstract}

Electronic supplementary material The online version of this article (doi:10.1007/s12542-014-0233-5) contains supplementary material, which is available to authorized users.

A. M. Forasiepi $(\bowtie) \cdot$ E. Cerdeño

Paleontología, IANIGLA, CCT-CONICET Mendoza,

Av. Ruiz Leal s/n, 5500 Mendoza, Argentina

e-mail: borhyaena@hotmail.com

E. Cerdeño

e-mail: espe@mendoza-conicet.gob.ar

A. M. Forasiepi · F. R. Straehl

Paläontologisches Institut und Museum,

Universität Zürich, Karl Schmid-Strasse 4, 8006 Zurich,

Switzerland

e-mail: fiona_s@gmx.net

\section{Bond}

División Paleontología de Vertebrados, Museo de La Plata, Paseo del Bosque s/n, B1900 La Plata, Buenos Aires, Argentina e-mail: constantino1453@yahoo.com.ar

\section{G. I. Schmidt}

Laboratorio de Paleontología de Vertebrados, Centro de Investigaciones Científicas y Transferencia de Tecnología a la Producción (CICYTTP-CONICET), Materi y España,

3105 Diamante, Entre Ríos, Argentina

e-mail: gschmidt@cicyttp.org.ar dental features, and close comparisons were made with the Patagonian Nesodon imbricatus, common in the Santa Cruz Formation (Santacrucian Age, Early Miocene). The material is of a similar size to $N$. imbricatus, with a body mass estimation of about $550 \mathrm{~kg}$. The phylogenetic analysis groups $N$. taweretus sp. nov. with other species of Nesodon. The absolute age of the Aisol Formation has been established at ca $19.480 \pm 0.025 \mathrm{Ma}$ (Burdigalian; Early Miocene) by means of $\mathrm{U}-\mathrm{Pb}$ zircon dating. The vertebrate association is encompassed by the Santacrucian Age. Latitudinal separation between Mendoza and Patagonia in the south would have favored taxonomic differences, as reflected in the species of Nesodon.

\section{Naipauer \\ Instituto de Estudios Andinos "Don Pablo Groeber" (FCEyN, Universidad de Buenos Aires-CONICET), Pab. 2, Ciudad \\ Universitaria, C1428EHA Buenos Aires, Argentina \\ e-mail: maxinaipauer@gl.fcen.uba.ar}

A. G. Martinelli

Departamento de Paleontologia e Estratigrafia, Instituto de Geociências, Universidade Federal do Rio Grande do Sul, Ave. Bento Gonçalves, 9500, Porto Alegre, RS 91540-000, Brazil

e-mail: agustin_martinelli@yahoo.com.ar

\section{A. C. Garrido}

Museo Provincial de Ciencias Naturales "Profesor Dr. Juan A.

Olsacher", Etcheluz y Ejercito Argentino, 8340 Zapala,

Neuquén, Argentina

e-mail: albertocarlosgarrido@gmail.com

M. D. Schmitz · J. L. Crowley

Boise State University, 1910 University Drive, Boise,

ID 83725-1535, USA

e-mail: markschmitz@boisestate.edu

J. L. Crowley

e-mail: jimcrowley@boisestate.edu 
Keywords Nesodon - South America - Cenozoic · Early Miocene $\cdot \mathrm{U}-\mathrm{Pb}$ (CA-ID-TIMS) tuff age

Kurzfassung Wir beschreiben eine neue Art der Toxodontiden, Nesodon taweretus sp. nov., aus der AisolFormation in der Provinz Mendoza, im Zentralwesten von Argentinien. Nesodon ist ein häufig vorkommendes Taxon der Toxodontidae, die zu den Notoungulaten, einer ausgestorbenen Gruppe von endemischen Säugetieren des Känozoikums in Südamerika, gehören und den rezenten gehuften Ungulata ökologisch ähnlich waren. Der Holotyp von $N$. taweretus sp. nov. ist ein Schädel, dem wir vorläufig einige Unterkieferfragmente und postkraniale Knochen zuweisen. $N$. taweretus sp. nov. unterscheidet sich von den anderen Nesodon-Arten in mehreren Merkmalen des Schädels und der Bezahnung. Enge Vergleiche wurden mit dem aus Patagonien stammenden und in der Santa-CruzFormation (Santacruzium, frühes Miozän) verbreiteten Nesodon imbricatus gemacht. Das Material ist von ähnlicher Grösse wie N. imbricatus, Schätzungen der Körpermasse ist etwa $550 \mathrm{~kg}$. Die phylogenetische Analyse gruppiert $N$. taweretus sp. nov. mit anderen Arten von Nesodon. Das absolute Alter der Aisol-Formation wurde mittels der $\mathrm{U}-\mathrm{Pb}$ Zirkondatierung auf etwa $19.480 \pm 0.025 \mathrm{Ma}$ (Burdigalium, Unteres Miozäns) gesetzt. Die Wirbeltiervergesellschaftung in das Santacruzium eingeschlossen worden. Latitudinale Trennung zwischen Mendoza und Patagonien im Süden hätte taxonomischen Unterschiede begünstigt, wie das anhand der Arten von Nesodon widergegeben ist.

Schlüsselwörter Nesodon - Südamerika - Känozoikum · frühes Miozän · U-Pb (CA-ID-TIMS) Tuff Datierung

\section{Introduction}

For more than a century, Patagonia in Southern Argentina has provided rich fossil localities for the study of Cenozoic mammals. Age calibrations, coupled with the quality and the quantity of the Patagonian fossil record, provide excellent material to diagnose the evolutionary history of the South American biota. The north of South America has provided a less fecund fossil record and has demonstrated a different taxonomic composition to the southern part of the continent (e.g., the Paleogene from Santa Rosa, Peru; the Oligocene from Salla, Bolivia; the Miocene from La Venta, Colombia, and Urumaco, Venezuela; Kay et al. 1997; Campbell 2004; Sánchez Villagra et al. 2010; Shockey and Anaya 2008). Mendoza Province in central-western Argentina lies to the north of the windswept plains of Patagonia, and is in a suitable geographical location to provide data linking both biogeographic scenarios of the South American vertebrate evolution.
Mendoza Province has been the subject of new paleontological studies in the last few years, with a great deal of information on the evolution and distribution of Cenozoic mammals coming to light (Cerdeño 2011). One of the areas studied and prospected is the Aisol Formation outcropping in the San Rafael Department, in the center of the province (Fig. 1a) (Forasiepi et al. 2009, 2011; Vucetich et al. 2011). The Aisol Formation outcrops in isolated deposits that are exposed on the San Rafael Block and mainly associated with the Atuel and Diamante rivers (Dessanti 1954, 1956; González Díaz 1972; Sepúlveda et al. 2001, 2007). Several fossiliferous localities have been found in the area, with the richest being the Arroyo Seco de la Frazada (Fig. 1a). The stratigraphy of the Aisol Formation has been subject of recent revisions (Forasiepi et al. 2011). Here, the Aisol Formation corresponds to the lower section (LS) described by Forasiepi et al. (2011; Fig. 1b). The fossil vertebrate association includes Anura, Testudininae, Xenarthra, Notoungulata, Litopterna, and Rodentia (Forasiepi et al. 2011). To date, the chronology of the Aisol Formation has been controversial. Early authors suggested that the unit was deposited during the late Early Miocene (Santacrucian Age; Dessanti 1954, 1956; González Díaz 1972). Later fossil mammal finds suggested a middle Miocene age (Friasian s.l. sensu Soria 1983 or Colloncuran sensu Forasiepi et al. 2011). This contribution presents a new radiometric dating of a $19.480 \pm 0.025$ Ma tuff bed, which constrains the absolute age of the mammalian assemblage at these latitudes to the Early Miocene.

The Notoungulata is a diverse and abundant clade of extinct South American ungulates recorded from the Paleocene to the Pleistocene (Bond et al. 1995; Bond 1999). Following the formation of the Panama Bridge, the distribution of the group increased from South America to Central and North America (Polaco et al. 2004; Lundelius et al. 2013). Their phylogenetic affinities are still unclear. Notoungulates were related to other South American native ungulates (Astrapotheria, Litopterna, Pyrotheria, and Xenungulata) in the group Meridiungulata (McKenna 1975). However, recent analyses dealing with the main phylogenetic relationships of placental mammals recorded affinities of notoungulates and Afrotheria (O'Leary et al. 2013).

Toxodontids are medium to large Notoungulata of the Suborder Toxodontia, characterized by a specialized anterior dentition, with hypselodont incisor tusks and hypsodont molars. Toxodontids diversified during the Cenozoic and presented the richest diversity in the Miocene (Cifelli 1985; Marshall and Cifelli 1990; Nassif et al. 2000). During the Early and Middle Miocene, toxodontids were represented by Nesodon imbricatus, $N$. conspurcatus, $N$. cornutus (Santacrucian SALMA in Argentina and Chile); Adinotherium ovinum and A. robustum (Santacrucian SALMA in Argentina); Proadinotherium muensteri (Colhuehuapian 
SALMA in Argentina); Palyeidodon obtusum (Friasian s.s. and Colloncuran SALMAs in Argentina, Bolivia, and Chile), Hyperoxotodon speciosus (Santacrucian-Colloncuran SALMAs in Argentina and Chile), and Pericotoxodon platignathus (Laventan SALMA in Colombia) (e.g., Pascual 1954; Marshall et al. 1983; Madden 1990, 1997; Nassif et al. 2000; Croft et al. 2003, 2004, 2009; Kramarz et al. 2005; Croft 2007). In addition, Quebrada Honda (Laventan SALMA in Bolivia) produced material that was referred to cf. Paratrigodon (Croft 2007); Cojitambo (Santacrucian? SALMA in Ecuador) produced Pericotoxodon sp. (Madden 1990); Chucal (Santacrucian SALMA in Chile) produced ?Palyeidodon (Bond and García 2002; alternative interpretation in Croft et al. 2004, 2009), and Río Collón Curá and Meseta de la Barda Negra (Colloncuran SALMA in Neuquén Province, Argentina) produced Nesodon sp. (Kramarz et al. 2011b). The genus Nesodon was abundant in the late Early Miocene and it was considered a taxon guide for the Santacrucian Age (Croft et al. 2003), although its record in the Colloncuran (Kramarz et al. 2011b) demonstrated that the genus continued to later ages.

The toxodontid remains recovered from the Aisol Formation (Forasiepi et al. 2011) consist of two well-preserved skulls, mandibular remains, and isolated postcranial elements. The analysis of the skull and tooth morphology allowed the recognition of two taxa: Palyeidodon cf. P. obtusum and a new Nesodontinae taxon (Forasiepi et al. 2011). This contribution provides a detailed systematic study of this taxon, recognized as a new species of Nesodon, the analysis of its phylogenetic relationships, and an estimation of its body mass.

\section{Abbreviations}

$A M N H$, American Museum of Natural History, New York, USA. MACN, Museo Argentino de Ciencias Naturales "Bernardino Rivadavia" ( $A$, Ameghino Collection; $P V$, Vertebrate Paleontology Collection; $S C$, Santa Cruz Province Collection), Buenos Aires, Argentina. MHNSR-PV, Museo de Historia Natural de San Rafael, Vertebrate Paleontology Collection, San Rafael, Mendoza, Argentina. YPM PU, Yale Peabody Museum, Collection of Princeton University, New Haven, USA.

In the description of teeth and the corresponding tables, we use the following abbreviations: $L$, length. $M / m$, upper/ lower molar. $P / p$, upper/lower premolar. $W$, width.

\section{Materials and methods}

\section{Dating}

Tuff samples were collected from the Aisol Formation to determine the absolute age by $\mathrm{U}-\mathrm{Pb}$ zircon analysis via a combination of laser ablation inductively coupled plasma mass spectrometry (LA-ICPMS) and chemical abrasion isotope dilution thermal ionization mass spectrometry (CAID-TIMS). Tuff level 2 (Fig. 1b) was chosen as the most appropriate sample for dating based on its mineralogical composition and grain size. Approximately $3 \mathrm{~kg}$ of rock were processed in the Boise State University Isotope Geology Laboratory for zircon separation, cathodoluminescence (CL) images, and isotopic analysis; see the Electronic supplementary material (ESM) 1. An abundant population of large (approximately 100-300 microns in the major dimension), moderate to highly elongate prismatic zircon crystals were separated by conventional density and magnetic methods. The crystals were placed in a muffle furnace at $900{ }^{\circ} \mathrm{C}$ for $60 \mathrm{~h}$ in quartz beakers to anneal minor radiation damage. Annealing enhances cathodoluminescence (CL) emission, promotes more reproducible interelement fractionation during LA-ICPMS, and prepares the crystals for subsequent chemical abrasion (Mattinson 2005). Following annealing, individual grains were handpicked and mounted, polished, and imaged by CL on a scanning electron microscope. From these compiled images, grains with consistent and dominant CL patterns were selected for further isotopic analysis.

$\mathrm{U}-\mathrm{Pb}$ geochronology and trace element analysis by LAICPMS followed the methods described in Rivera et al. (2013) using a ThermoElectron X-Series II quadrupole ICPMS and a New Wave Research UP-213 Nd:YAG UV $(213 \mathrm{~nm})$ laser ablation system. In-house analytical protocols, standard materials, and data reduction software were used for acquisition and calibration of $\mathrm{U}-\mathrm{Pb}$ dates and a suite of high field strength elements (HFSE) and rare earth elements (REE). U- $\mathrm{Pb}$ and ${ }^{207} \mathrm{~Pb} /{ }^{206} \mathrm{~Pb}$ ratios and dates for unknowns were calibrated via interspersed measurements of the Plešovice zircon standard (Sláma et al. 2008). Signals at mass 204 were indistinguishable from zero following subtraction of mercury backgrounds measured during the gas blank $\left(<1,000 \mathrm{cps}{ }^{202} \mathrm{Hg}\right)$, so dates are reported without common $\mathrm{Pb}$ correction. Radiogenic isotope ratio and age error propagation for all analyses includes uncertainty contributions from counting statistics and background subtraction. A zircon secondary reference material AUSZ2 [38.9 Ma from unpublished chemical abrasion thermal ionization mass spectrometry (CA-TIMS) data, Boise State University] was interspersed as pairs of analyses for every 20 unknown analyses, and yielded a weighted mean ${ }^{206} \mathrm{~Pb} /{ }^{238} \mathrm{U}$ date of $38.6 \pm 1.5 \mathrm{Ma}(\mathrm{MSWD}=2.1, n=8)$.

$\mathrm{U}-\mathrm{Pb}$ geochronology by isotope dilution thermal ionization mass spectrometry follows the methods described by Davydov et al. (2010) and Schmitz and Davydov (2012). Zircon crystals were subjected to a modified version of the chemical abrasion method of Mattinson (2005), reflecting a preference for preparing and analyzing selected single 

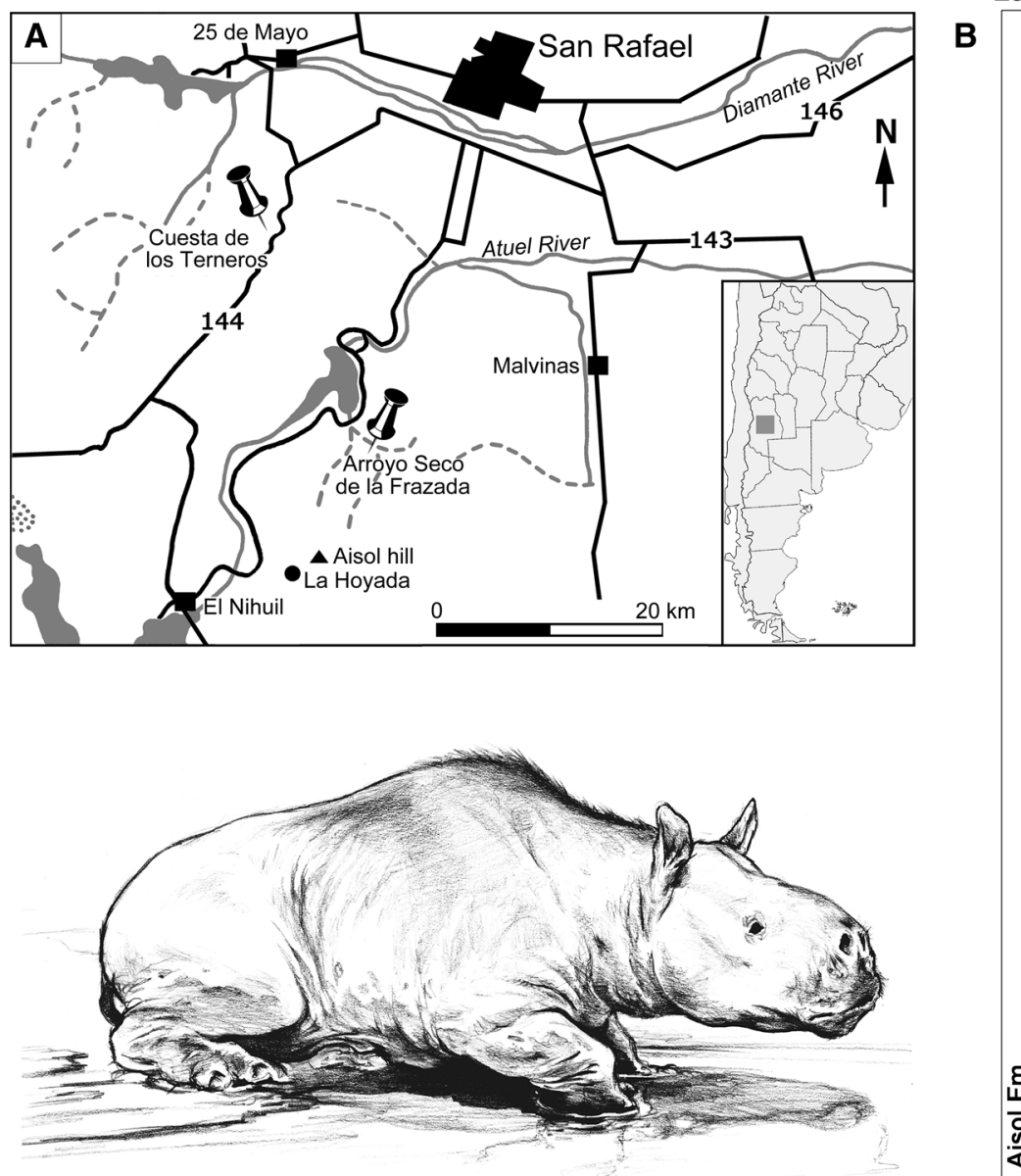

La Hoyada

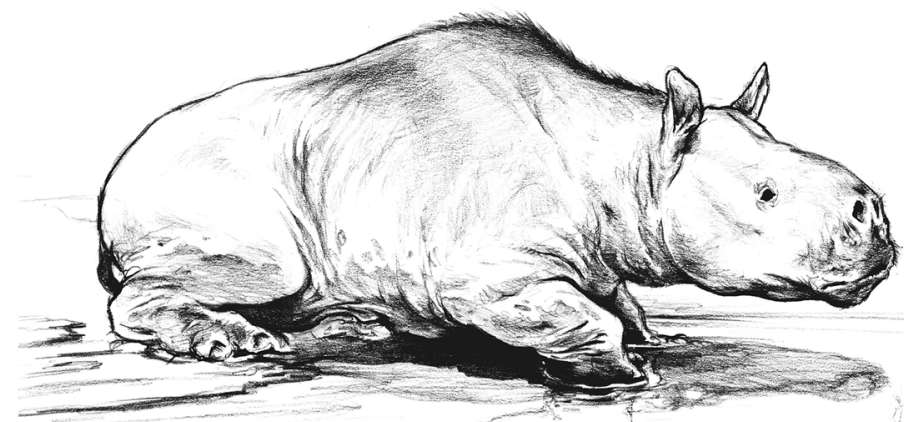

References:

\begin{tabular}{|c|c|c|c|}
\hline , & Conglomerate & $\equiv$ & Horizontal stratification \\
\hline & Sandstone & $\underline{\underline{\underline{\underline{\underline{\underline{E}}}}}}$ & Planar lamination \\
\hline & Tuffaceous sandstone & 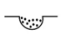 & Cut and filling \\
\hline & Silty sandstone & $\triangle$ & Intraclasts \\
\hline & Mudstone & $d$ & Rhizolith \\
\hline & Claystone & $\checkmark$ & Bioturbation \\
\hline & Tuff & (3) & Ichnite \\
\hline$\underline{\underline{\underline{11}}}$ & Cross stratification & 䭪 & Trunk \\
\hline 世еш & $\begin{array}{l}\text { Through cross- } \\
\text { stratification }\end{array}$ & है? & Fossil vertebrates \\
\hline$\cdots$ & $\begin{array}{l}\text { Low angle cross- } \\
\text { stratification }\end{array}$ & 1 & $\begin{array}{l}\text { MHNSR-PV } 1004 \\
\text { Zircon sampling }\end{array}$ \\
\hline
\end{tabular}


४Fig. 1 Geographic and stratigraphic occurrence of Nesodon taweretus sp. nov. a Locations of the Arroyo Seco de la Frazada and Cuesta de los Terneros fossil sites, Mendoza Province, Argentina. b Stratigraphic columns exposed at the localities of La Hoyada (left) and Arroyo Seco de la Frazada (right). Artistic reconstruction created by Jorge Blanco

crystal fragments. All analyses were undertaken on crystals that had previously been mounted, polished, and imaged by cathodoluminence (CL), and selected on the basis of zoning patterns. U-Pb dates and uncertainties for each analysis were calculated using the algorithms of Schmitz and Schoene (2007) and the U decay constants of Jaffey et al. (1971). Uncertainties are based upon non-systematic analytical errors, including counting statistics, instrumental fractionation, tracer subtraction, and blank subtraction. These error estimates should be considered when comparing our ${ }^{206} \mathrm{~Pb} /{ }^{238} \mathrm{U}$ dates with those from other laboratories that used tracer solutions calibrated against the EARTHTIME gravimetric standards. When comparing our dates with those derived from other decay schemes (e.g., $\left.{ }^{40} \mathrm{Ar} /{ }^{39} \mathrm{Ar},{ }^{187} \mathrm{Re}-{ }^{187} \mathrm{Os}\right)$, the uncertainties in tracer calibration (0.05\%; Condon et al. 2007) and U decay constants (0.108\%; Jaffey et al. 1971) should be added to the internal error in quadrature. Quoted errors for calculated weighted means are thus of the form $\pm X(Y)[Z]$, where $X$ is solely analytical uncertainty, $Y$ is the combined analytical and tracer uncertainty, and $Z$ is the combined analytical, tracer, and ${ }^{238} \mathrm{U}$ decay constant uncertainty.

\section{Systematics}

The description of the skull MHNSR-PV 1004 is organized according to the principal regions: facial, palatal, orbital, vault, and base. The nomenclature for the basicranium and orbitotemporal region corresponds to Gabbert (2004), but we use the names "paracondylar process" (instead of jugular process) following the veterinary nomenclature (Schaller 1992), "jugular fossa" (instead of jugular incisure) following Kielan-Jaworowska et al. (1986) and referring to the depression that contain the jugular foramen, and "sphenorbital fissure" (instead of orbitorotundum) following Wible and Gaudin (2004) and Billet (2010). The nomenclature of MacPhee (2014) is also referenced. For dental anatomy, we follow Madden (1990) and Nassif et al. (2000). The microstructure of the bone is described according to the nomenclature of Francillon-Vieillot et al. (1990). The bone sample was taken from the middle of the diaphysis because this level shows the least secondary remodeling and gives the most complete growth record (Francillon-Vieillot et al. 1990).

Comparisons are focused on nesodontines from the Santa Cruz Formation (Santacrucian Age), particularly with Nesodon imbricatus (MACN-A 5305) and Adinotherium ovinum (MACN A 5346 and MACN-SC 4355). Other Santacrucian species such as $N$. conspurcatus and $N$. cornutus are poorly characterized, but comparisons with them are included when possible.

Cladistic methodology with TNT (Goloboff et al. $2008 b$ ) was used to explore the phylogenetic relationships. Measurements are provided in Table 1 . The body mass was estimated following Cassini et al. (2012: tables 14.1 and 14.2), which include dental and cranial variables. The estimation is based on the average of the equations of Mendoza et al. (2006) and Janis (1990) after the weighting formula of Christiansen and Harris (2005: 371) (ESM 2).

\section{Geological data and geochronological interpretations}

The Aisol Formation refers here to the lower section (LS) proposed by Forasiepi et al. (2011), following recent interpretations (Garrido 2014, personal observation). The unit represents a sequence of epiclastic rocks of fluvial origin, associated with pyroclastic rocks. The succession is mainly formed from mudstones and medium- to finegrained sandstones with tones varying from pale red to yellow, brown, and white. The sandstones are well stratified and often occur in massive banks with cross-stratification (Sepúlveda et al. 2001).

The base of the Aisol Formation is shown in detail in La Hoyada (Fig. 1b). In this area, the succession is about $100 \mathrm{~m}$ thick, settling on a Paleozoic metamorphic carved paleorelief. At the base of the profile, there are three cineritic tuff levels. Zircons used for dating were collected from the second level of tuff in the stratigraphic sequence of La Hoyada site (Fig. 1b). Fossil vertebrates from La Hoyada were collected by Soria (1983), indicated as coming from Cerro Aisol (Fig. 1a).

The lithofacial analysis suggests the development of a low-sinuosity fluvial system, associated with a muddy floodplain with abundant volcanic ash and insufficient development of paleosoils. The paleochannel configurations and their constitutive facies show a gradual reduction of its energy towards the upper part of the succession, changing from gravelly to medium-grained sandy channel deposits. The available information suggests the presence of major perennial streams, which would positively influence the development of the paleobiota (Sepúlveda et al. 2001).

The abundant pyroclastic content within the floodplain deposits indicates the existence of volcanic activity along this cycle of deposition. The fine grain size of the tuffs and their presence in very thin horizons suggest an origin as distal ash fall deposits, located far from the emission center (Teruggi et al. 1978; Mazzoni 1986). 


\section{Zircon populations and geochronological data}

CL imaging of 98 zircon crystals separated from the level-2 tuff sample revealed a bimodal population of grains: a predominant subgroup of moderately to brightly luminescent, weakly oscillatory to planar zoned crystals, which includes all elongate and many more equant crystals and a subsidiary subgroup of less intensely luminescent to nonluminescent crystals that exhibit stronger oscillatory and occasional sector zoning. Some crystals of the predominant luminescent subgroup have irregularly shaped, relatively non-luminescent cores overgrown by the luminescent rims, suggesting that this dominant subgroup is the primary magmatic population of the tuff, while the less luminescent grains and cores may be inherited or recycled from earlier volcanism. Seventy-four spot analyses by LA-ICPMS confirmed the presence of inherited cores and grains of Mesoproterozoic to Eocene age, coexisting with what may be interpreted as a single Miocene population of zircon represented by 44 spot analyses with a weighted mean age of $19.4 \pm 0.3 \mathrm{Ma}$.

Six grains were selected for CA-TIMS analysis on the basis of morphology and CL pattern, avoiding those crystals with obvious resorbed non-luminescent cores but including five elongate grains ( $z 1, z 3, z 4, z 5$, and, z6) from the primary population and one grain (z2) from the secondary population. Four of the six analyses are concordant and equivalent, with a weighted mean ${ }^{206} \mathrm{~Pb} /{ }^{238} \mathrm{U}$ date of $19.480 \pm 0.009(0.013)$ [0.025] Ma (MSWD $=0.85)$, which is interpreted as dating the eruption and deposition of this tuff (Fig. 2). Two other crystals yielded older ${ }^{206} \mathrm{~Pb} /{ }^{238} \mathrm{U}$ dates of 19.55 and 20.31 Ma, the latter from the more strongly zoned secondary population of grains, supporting the inference from CL imagery and LA-ICPMS analysis of nuclei of inherited zircons in some magmatic grains (ESM 1, which includes a complete list of the analytical data).
Fig. 3 Skull MHNSR-PV 1004 of Nesodon taweretus sp. nov. in lateral (a), dorsal (b), and ventral (c) views. crm Crista meatus, frp frontal process of jugal, $g f$ glenoid fossa, inf incisive foramen, iof infraorbital foramen, lacf lacrimal foramen, mifp minor palatine foramen, $m p f$ major palatine foramen, $m p p$ medial palatine process of premaxilla, $m x f$ maxillary foramen, $n c r$ nuchal crest, $n f$ nutrient foramen, $n p l$ narial platform, oc occipital condyle, palf palatine foramen, pap paracondylar process of exoccipital, pgp postglenoid process, $p l p x$ posterolateral process of premaxilla, pop postorbital process of frontal, $p p$ postpalatine apophysis, $p t$ pterygoid, $p t p$ posttympanic process of squamosal, ram temp foramina for rami temporales, $s c r$ sagittal crest, $s t p$ styliform process, $t l$ temporal line

\section{Systematic paleontology}

\section{Notoungulata \\ Toxodontidae \\ Nesodontinae \\ Nesodon Owen 1846 \\ Nesodon taweretus sp. nov.}

Figures 3, 4, 5, 6, 7, 8, and 9

Derivation of name. Egyptian deity Taweret, meaning "she who is great" or "great one," usually represented by the body of a hippopotamus, which reflects the robust appearance of the new species.

Holotype. MHNSR-PV 1004, mostly complete skull with right M1-M3 badly preserved and remains of the left molars. Alveoli of the remaining teeth are preserved, but the area of $\mathrm{I1}$ is damaged.

Referred material. MACN-PV 18609, isolated upper molar.

Tentatively assigned material. MHNSR-PV 360, right mandible with part of the symphysis, remains of right i1 and i3, and p4 (broken)-m3; MHNSR-PV 1000, incomplete lower jaw with right $\mathrm{m} 1-\mathrm{m} 3$ and left $\mathrm{m} 1$ and m3. MHNSR-PV 122, distal fragment of left femur;
Fig. $2 \mathrm{U}-\mathrm{Pb}$ concordia diagram for zircon analyses from dated tuff (level 2 sample). The four red filled ellipses are included in weighted mean calculations

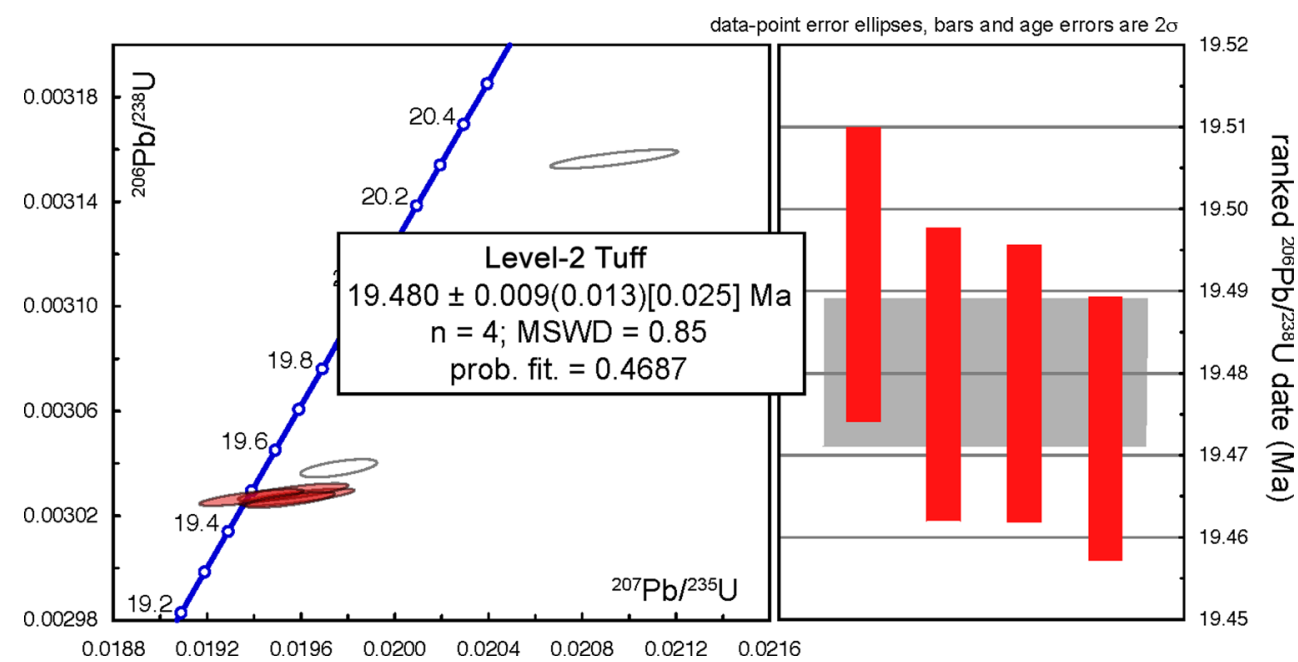




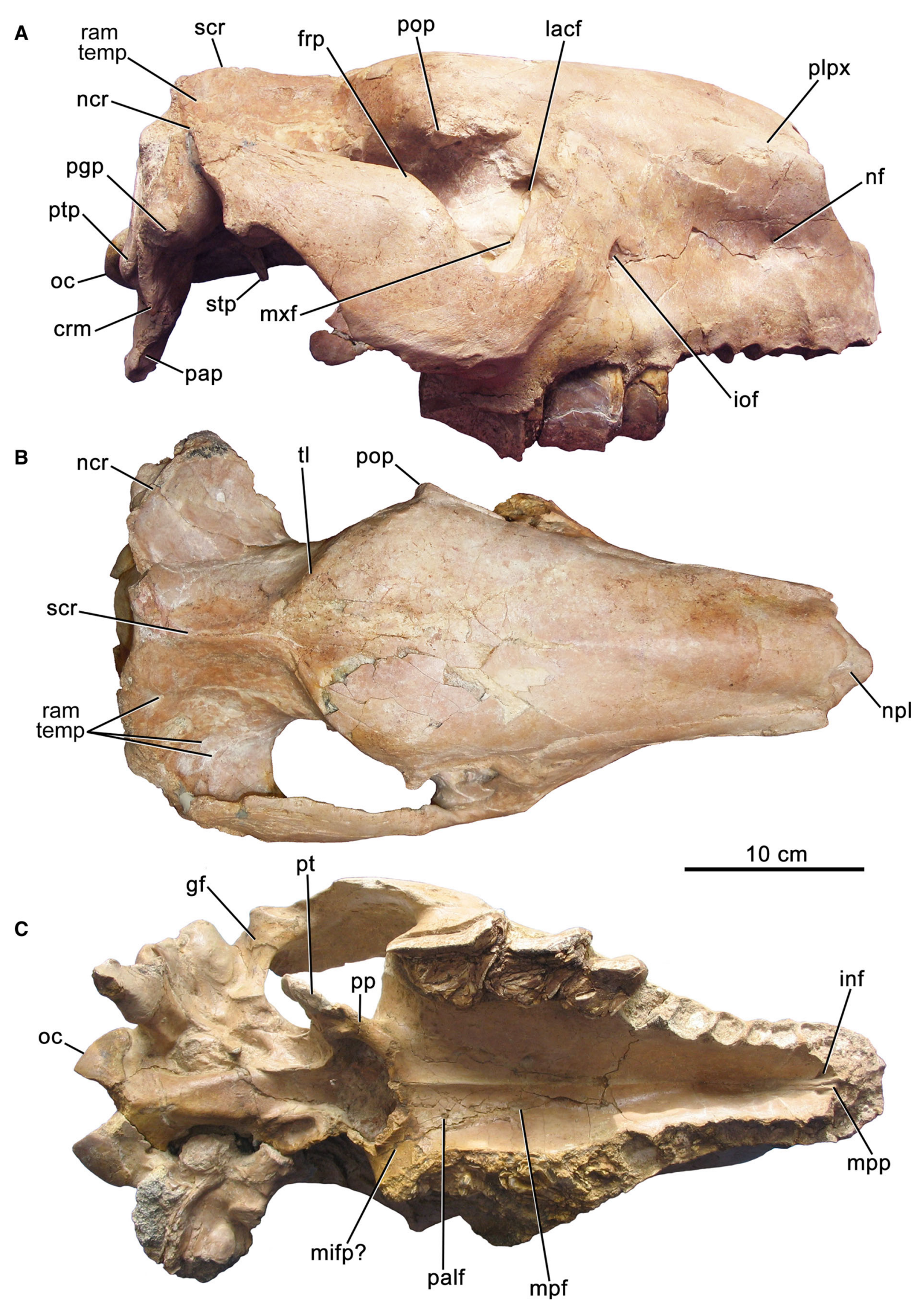


MHNSR-PV 1008, incomplete right ulna; MHNSR-PV 1009, left ulna lacking the distal epiphysis; MHNSR-PV 1010, complete left ulna.

Remarks. The mandibular fragments MHNSR-PV 360 and MHNSR-PV 1000 are assigned to the new species in contrast with two other fragments from the Aisol Formation, MHNSR-PV 1001 (right dentary fragment with $\mathrm{m} 3$ and partial m2) and MHNSR-PV 1075 (left dentary with the posterior part of the symphysis and p4-m3; ESM 2), whose larger size and morphological features (see description) promotes them as Palyeidodon, the second toxodontid recovered from the Aisol Formation. However, some characters are inconclusive for a precise determination.

The postcranial bone morphologies of specimens MHNSR-PV 122, MHNSR-PV 1008, MHNSR-PV 1009, and MHNSR-PV 1010 agree with the morphology of the postcranium described for Nesodon (Scott 1912). No postcranial material of Palyeidodon is currently identified, so our tentative assessment is to equate the new specimens with the new taxon.

Occurrence. The specimens MHNSR-PV 1000, MHNSRPV 1004, MHNSR-PV 1008, MHNSR-PV 1009, MHNSRPV 1010, and MACN-PV18609 come from the Arroyo Seco de la Frazada (the holotype, MHNSR-PV 1004, comes from $34^{\circ} 53^{\prime} 57.3^{\prime \prime} \mathrm{S} / 68^{\circ} 28^{\prime} 52.6^{\prime \prime} \mathrm{W}$ ); MHNSR-PV

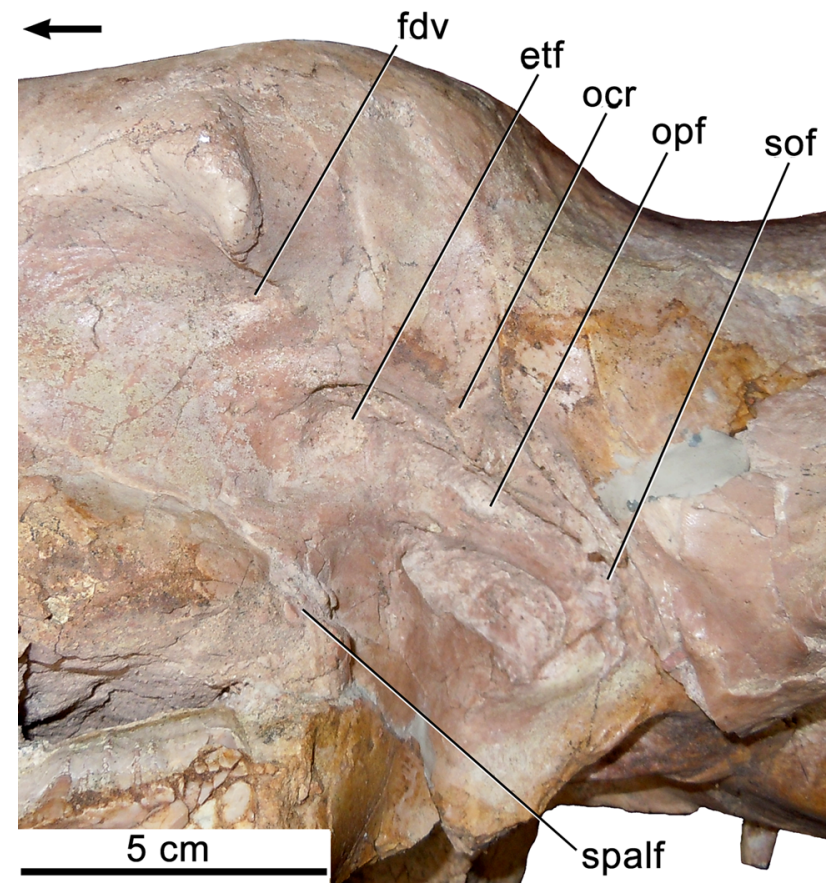

Fig. 4 Detail of the skull MHNSR-PV 1004 of Nesodon taweretus sp. nov. in lateral view. etf Ethmoidal foramen, $f d v$ frontal diploic vein foramen, ocr orbital crest, opf optic foramen, sof sphenorbital fissure, spalf sphenopalatine foramen. The arrow indicates anterior
360 and MHNSR-PV 122 come from Cuesta de los Terneros, Arroyo Cochicó; San Rafael Department, Mendoza Province, Argentina. Aisol Formation (Santacrucian Age).

Diagnosis. Species of Nesodon with a robust skull. N. taweretus differs from $N$. imbricatus in the following features: longer dorsal convexity, especially at the posterolateral border of frontals; W-shaped instead of U-shaped and slightly more retracted anterior border of nasals behind the anterior border of premaxilla; zygoma very deep at the level of the frontal process and with its maximum width at its median part instead of at the back; border of the choana at the level of the posterior border of M3; proportionally longer basicranium; lower basisphenoid-basioccipital tuberosities and lower median keel; more vertical occipital condyle; laterally instead of medially oriented paracondylar process; I2-I3-C without diastema; and molars with less persistent folds and fossettes. $N$. taweretus differs from $N$. cornutus by the lower and wider occiput.

\section{Description and comparisons}

\section{Skull and upper dentition}

The skull MHNSR-PV 1004 is slightly laterally compressed, but this does not affect the morphology or dimensions of different cranial sections. Similar to other toxodontids, the skull is narrow and tall. Several sutures are fused, including some in the facial region of the skull (e.g., lacrimal-frontal, jugal-maxilla), which usually remain open in late ontogenetic stages of other placentals (Krogman 1930; Rager et al. 2014). Consequently, MHNSR-PV 1004 can be considered a late adult or senile specimen.

In lateral view (Fig. 3a), the upper profile of MHNSRPV 1004 is shallowly sigmoid-shaped: it is convex at the level of the nasals and frontals, depressed at the level of the temporal region, and raised again at the level of the nuchal crest. In $N$. imbricatus, the dorsal convexity does not include the posterior part of the frontals and it varies from an almost flat upper profile (Scott 1912) to steeply rising from the forehead to the occiput (Scott 1912; per. obs.). After Scott (1912: figs. 35-36), N. cornutus has a more raised sagittal crest and less convex nasals; unfortunately, the type specimen YPM PV 16012 now lacks its posterodorsal region. In dorsal view (Fig. 3b), MHNSR-PV 1004 is roughly triangular in outline, with shallower prezygomatic constrictions and less expanded zygomatic arches than in N. imbricatus.

Face. The face is high, as is typical for herbivores, and formed by the premaxilla, maxilla, and nasal. In lateral view, 
Fig. 5 Detail of the basicranium of MHNSR-PV 1004, Nesodon taweretus sp. nov. $b$ Auditory bulla, $b c f$ basicoclear fissure, $\mathrm{crm}$ crista meatus, et groove for passage of Eustachian tube, $g f$ glenoid fossa, $h f$ hypoglossal foramen, $h r$ hyoid recess, if jugular fossa, $m k$ median keel, oc occipital condyle, pap paracondylar process of exoccipital, $p g f$ postglenoid foramen, $p g p$ postglenoid process, $p t$ pterygoid, $p t p$ post-tympanic process of squamosal, $s f$ scaphoid fossa, smf stylomastoid foramen, spf sphenotympanic fissure, stp styliform process, $t$ tuberosity
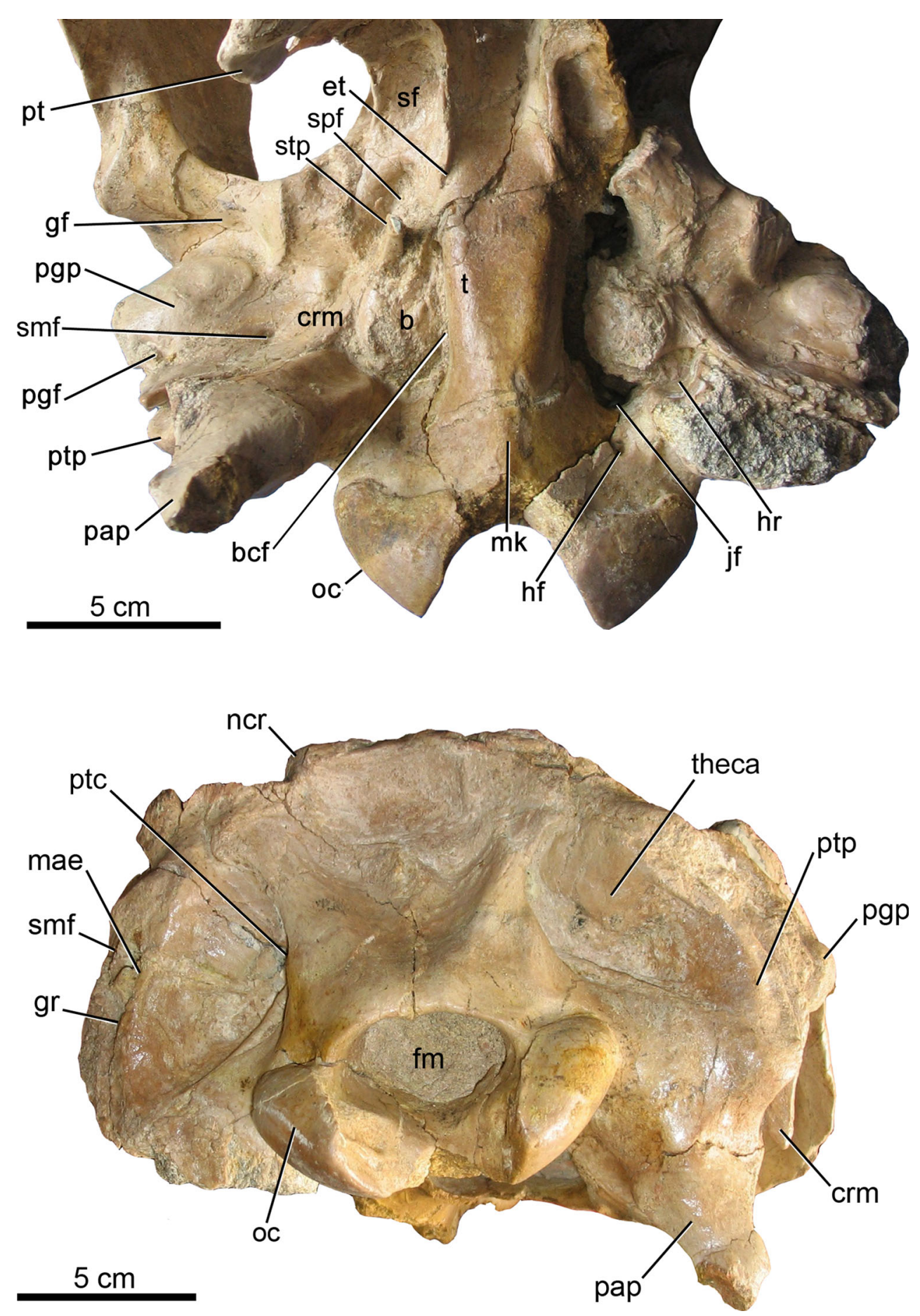

Fig. 6 Skull MHNSR-PV 1004 of Nesodon taweretus sp. nov. in occipital view. crm Crista meatus, $f m$ foramen magnum, $g r$ groove, mae external acoustic meatus, $n c r$ nuchal crest, $o c$ occipital condyle, pap paracondylar process of exoccipital, $p g p$ postglenoid process, $p t c$ posttemporal canal, $p t p$ post-tympanic process of squamosal, smf suprameatal foramen, theca (bony covering of the epitympanic simus) the premaxilla is slightly wider ventrally than dorsally. A very short posterolateral process interposes between the nasal and the maxilla. There are tiny foramina close to the premaxillo-maxillary suture and a large nutrient foramen on the right side of the skull (Fig. 3a). The narial platform is exposed in dorsal view. Similar to N. imbricatus, it has a small, blunt and dorsally projected anterior process.
The anterior nasal aperture is diamond shaped, narrower ventrally than dorsally and wider at the mid-dorsal half. The nasals are dorsally convex, with their anterior tip somewhat retracted from the anterior end of the premaxilla. The anterior border of the nasals is $\mathrm{W}$-shaped. The nasals extend posteriorly to the level of the orbit and contact the frontal by means of a broad W-shaped suture; 
this suture is an acute $\mathrm{W}$ in $N$. imbricatus and $\mathrm{U}$-shaped in $N$. cornutus.

The maxilla is high and the main component of the snout in lateral view. It has a shallow groove at the level of the premolars, similar to N. imbricatus (Scott 1912). The infraorbital foramen is small and opens at the level of the anterior border of $\mathrm{M} 2$, as in $N$. imbricatus. The maxillary foramen is compressed against the zygomatic arch.

\section{Palate}

In ventral view, the premaxilla, maxilla, palatine, and pterygoids are exposed (Fig. 3c) with feebly distinguished sutures. The maxillo-palatine suture is V-shaped, with the palatine narrower and longer than in $N$. imbricatus. The palate is triangular, narrow, and deeply concave at the level of the premolars, becoming shallower and wider backward, especially at the level of M3. According to Scott (1912), the palate increases in depth with age, which supports the advanced ontogenetic stage suggested for MHNSR-PV 1004. At the midline of the palate, there is a thin crest that rises at the level of the posterior half of the $\mathrm{P} 2$ and reaches the choana. The small oval incisive foramina open in the premaxilla at the level of I2-I3. Lateral and medial incisive foramina are separated by a crest-like medial palatine process, similar to N. imbricatus. In MHNSR-PV 1004, a pair of large foramina open in the maxilla, at the level of the anterior part of $\mathrm{M} 2$, recognized as the major palatine foramina for the passage of the major palatine artery and nerve (Evans and deLahunta 1972). The palatine also has three small apertures at the anterior level of M3, one on the right side and two on the left side of the palate, as well as an extra aperture on the left palato-maxillary suture at the level of the posterior border of M3. These accessory openings probably transmitted bundles of the major palatine nerve and accompanying vessels, as occurred in some placentals (Wible and Gaudin 2004). The most posterior foramen on the horizontal process of the palatine likely corresponds to the minor palatine foramen for the passage to the soft palate of the minor palatine artery and nerve (Evans and deLahunta 1972).

In MHNSR-PV 1004, the posterior border of the palate and the border of the choana are aligned with the posterior border of the M3. This is different from N. imbricatus, in which the posterior border of the palate is oblique to the main axis of the skull, with the choana opening behind the level of M3 (Scott 1912). The choana in MHNSR-PV 1004 is single-arched and surrounded by blunt postpalatine apophyses that meet the pterygoid processes. The pterygoid processes are strongly divergent to the back, whereas in $N$. imbricatus they are straighter and much less divergent.

\section{Orbit}

The orbits are almost central to the skull (Fig. 3a), similar to N. imbricatus (Scott 1912). The lacrimal is small and exposed on the orbit and orbital rim, where it has a long spine that directs ventrally, contacting the maxilla. The lacrimo-jugal suture observed in N. imbricatus is missing in MHNSR-PV 1004. There is a single and large lacrimal foramen opening inside the orbit. The lacrimal process is rudimentary.

The orbitotemporal fossa is better preserved on the left side of the skull (Fig. 4). Three openings that are aligned and dorsally bordered by the orbital crest are the sphenorbital fissure, the optic foramen, and the ethmoidal foramen. The sphenorbital fissure is the largest opening and is located in the posteroventral corner of the fossa. This would convey the maxillary and ophthalmic branches of the trigeminal nerve and the oculomotor, abducens, and trochlear nerves, as in bovids (Schaller 1992). The optic foramen is smaller and rostrodorsally placed to the sphenorbital fissure. The ethmoidal foramen is the smallest. A small foramen opens posteriorly and ventrally to the frontal process, and it is identified as the aperture for the frontal diploic vein (following Wible and Gaudin 2004, describing the anatomy of the yellow armadillo).

The sphenopalatine foramen opens ventral to the ethmoidal foramen and at the level of the posterior border of the M3 (Fig. 4). This aperture is large and directs to the nasal cavity. In lateral view, it faces posteriorly.

\section{Vault}

The vault comprises the frontal, the parietal, and possibly the interparietal, with a large significance of the frontal (Fig. 3b). At the postorbital level, the frontal bulks, probably due to well-developed frontal sinus, and defines a convex surface, very conspicuous and more pronounced than in N. imbricatus and N. cornutus (Scott 1912). The postorbital processes are small. MHNSR-PV 1004 has subtle temporal lines, unlike $N$. imbricatus and $N$. cornutus, in which temporal lines are sharper and separate from the sagittal crest ending at the postorbital process (e.g., AMNH 9168) or before reaching the process (Scott 1912). The parietal is narrow and mostly restricted to the posterior part of the skull roof. The sagittal crest is shorter and lower in MHNSR-PV 1004 than in N. imbricatus. The squamosal largely contributes to the skull vault by means of a large squamous process that is roughly semicircular in shape, similar to $N$. imbricatus. There are two large foramina in the left and three in the right temporal fossa, on the squamosal and parietal, and close to the nuchal crest. These foramina are recognized as the rami temporales of the 
stapedial artery and accompanying veins, following MacPhee (2014).

\section{Zygoma}

The zygomatic arch is short and robust and includes the jugal, squamosal, and a very short zygomatic process of the maxilla that forms its anterior base (Fig. 3a). The arch is very deep at the level of the frontal process, forming an angle between the front and the rear of the dorsal border of the arch. $N$. imbricatus displays an arch with a more constant depth. In ventral view (Fig. 3c), the maximum width of the arch is at its median part, while $N$. imbricatus displays the widest part of the arch at the back.

\section{Basicranium}

The good preservation of the specimen permits a detailed description of the basicranium (Fig. 5). Differences from $N$. imbricatus are expressed in absolute size and variations in proportions and the relative development of processes, crests, and tubercles.

The basicranium in MHNSR-PV 1004 is wide and long. Its length (measured from the level of the posterior choana to the posterior border of the condyle) is $39 \%$ of the total skull length, while it is $36.5 \%$ in $N$. imbricatus (Scott 1912: plate 15).

The occipital and sphenoid complexes form the floor of the braincase at midline; sutures between them are not visible. A pair of tuberosities develop close to the midline and medially to the bulla, and extend anteriorly up to the level of the sphenotympanic fissure. The specimen MACNSC 4355 of Adinotherium has stronger tuberosities on the basisphenoid-basioccipital, and the same bone arrangement is expected for MHNSR-PV 1004. These tuberosities converge posteriorly in a feeble and short median crest. $N$. imbricatus has more robust, taller, and parallel tuberosities and a sharper median crest (Scott 1912).

On each lateral side of the sphenoid complex, MHNSRPV 1004 shows a deep scaphoid fossa that would serve as an area of attachment for the tensor veli palatini muscles (Gabbert 2004). The fossa is surrounded by sharp medial and lateral crests. This fossa is shallower in N. imbricatus, with less developed crests.

The small auditory bulla is partially preserved on the right side of the skull. The bulla contacts the sphenoid complex anteriorly, the paracondylar process posteriorly, and the crista meatus posterolaterally (Fig. 5). The bulla does not contact the lateral edge of the sphenoid along the basicochlear (=basicapsular) fissure, but this space could be broadened by breakage. In N. imbricatus, the bulla and the basisphenoid are sutured. The auditory bulla is broken ventrally in MHNSR-PV 1004. In N. imbricatus, the bulla projects ventrally beyond the level of the braincase, and it is even further ventrally projected in Adinotherium. In toxodontids, the bulla and part of the floor that covers the external acoustic meatus (MAE) ventrally is formed by the ectotympanic (Gabbert 2004). The participation of the entotympanic in the auditory bulla (e.g., Patterson 1936 contra Gabbert 2004), which is apparently the case for some notoungulates (MacPhee 2014), would be resolved with the analysis of juveniles. The crista meatus, a projection of the ectotympanic (Gabbert 2004; MacPhee 2014), is sharp and long in MHNSR-PV 1004, increases in height posterolaterally, and ends in a robust process (Fig. 5). This is similar to N. imbricatus, but Adinotherium demonstrates a thinner process.

At the right side of the skull, a long vertical styliform process (following van der Klaauw 1931 and Patterson 1932) was preserved fused to the anterior part of the bulla (Fig. 5). Scott (1912) suggested that a similar process in $N$. imbricatus would correspond to the tympanohyal, probably fused to the stylohyal (tympanostyloid in MacPhee 2014), although in notoungulates the cranial end of the hyoid is a narrow bar, lodged within the hyoid recess (MacPhee 2014). Alternatively, the styliform process is located on the anterior end of the auditory bulla and forms the prolongation of the Eustachian tube (van der Klaauw 1931).

The auditory region of $N$. imbricatus has extraordinary specializations (Scott 1912). The MAE forms a long tube, enclosed by the postglenoid process anteriorly, the crista meatus, and the post-tympanic process posteriorly (Gabbert 2004), and opens at an elevated position. In MHNSR-PV 1004, the MAE is at the level of the mid-height of the occiput (Fig. 6); this is slightly lower than in N. imbricatus (Scott 1912). Ventral to the MAE, there is a sulcus ("incisura mastoidea" sensu Roth 1903) excavated between the crista meatus and post-tympanic process, and similar to the toxodontians described by Gabbert (2004: fig. 14.2). In MHNSR-PV 1004, anterior to the MAE there is a circular foramen, sligthly smaller than the MAE, which 
we recognized as the suprameatal foramen following Gabbert (2004).

The glenoid cavity (Fig. 3c) is anterolateral to the bulla and dorsal to the floor of the braincase, as in other nesodontines and other notoungulates (Patterson 1932, 1934). The glenoid cavity is broader than long and saddle-shaped. In lateral view, the cavity is sigmoidal in shape: anteriorly convex and posteriorly concave.

The postglenoid (=retroarticular) process is low and represented by a swelling of the squamosal, similar to $N$. imbricatus. There is a single aperture for the postglenoid (=retroarticular) foramen on the posterior wall of the postglenoid process. The post-tympanic (=retrotympanic) process is longer than the postglenoid process. In lateral view (Fig. 3a), the crista meatus interposes between both processes of the squamosal. There is a small foramen on the anterior base of the crista meatus (Fig. 5), identified as the stylomastoid foramen (following the topographic relationships of Cochilius in MachPhee 2014: figs. 13a, b).

Anterior to the bulla, there is a broad opening, the sphenotympanic fissure (Fig. 4) following Gabbert (2004) or piriform fenestra following MacPhee (2014). In the vicinity of the sphenotympanic fissure, independent carotid foramen, vidian foramen, and foramen ovale are not identified. All the soft tissues that these individual openings convey in other mammals would pass together through the sphenotympanic fissure in MHNSR-PV 1004, in common with other toxodontids (Gabbert 2004). On the sphenoid, there is a narrow groove that directs from the nasopharyngeal passage to the auditory cavity, ending at the anteromedial border of the sphenotympanic fissure that would contain the Eustachian tube. This groove is deeper in N. imbricatus.

Behind the bulla, the large jugular fossa is posteriorly bordered by the occipital complex. It is confluent with the basicochlear fissure. Lateral to the jugular fossa, bounded by the bulla anteriorly, the crista meatus anterolaterally, and the paracondylar process posteriorly, there is a deep depression identified as the hyoid recess for the tympanohyal and stylohyoid articulation (Gabbert 2004). The outline of the hyoid recess is slightly larger than the outline of the jugular fossa and oval in section, similar to N. imbricatus. There is a single hypoglossal foramen opening immediately posterior to the jugular fossa. This foramen is smaller than in N. imbricatus and Adinotherium.

In posterior view (Fig. 6), the occipital face is wide and low and defines a roughly semicircular outline, sim- ilar to $N$. imbricatus and different from the higher occiput of $N$. cornutus, which also has a higher sagittal crest (Scott 1912). The nuchal crests draw a semicircular curve, and they do not project further than the level of the occipital condyles. No sutures are observed in this area with the exception of part of the exoccipital-squamosal suture at the posterolateral corner of the occiput. There is no evidence of the mastoid process in the occipital view of MHNSR-PV 1004. According to Gabbert (2004), and differing from previous interpretations (Roth 1903; Scott 1912; Patterson 1932), the petrosal is not exposed in occipital view. The occiput in MHNSR-PV 1004 and other toxodontians is formed by the occipital complex and squamosal (Gabbert 2004; see also MacPhee 2014 for other notoungulates).

The foramen magnum is oval, with the main axis horizontal. The occipital condyles are oval and close to each other in ventral view (Figs. 3c, 5). The notch between the condyles is very deep. In lateral view, the condyles (Fig. 3a) project backwards from the occiput, but slightly less than in $N$. imbricatus. In posterior view (Fig. 6), the main axis of the condyle is vertical and the paracondylar process is laterally oriented instead of medially as in $N$. imbricatus, with a greater separation than in this taxon.

The occiput in MHNSR-PV 1004 (Fig. 6) has a deep depression, dorsal to the occipital condyle and at the level of the exoccipital-squamosal suture, with an aperture. In other notoungulates and pyrotheres, a similar opening was interpreted to be the mastoid foramen (Gabbert 2004; Billet 2010), but the possibility of being the posttemporal canal could not be discarded for some native ungulates (Kramarz et al. 2011a). In the specimen MACN 5305 of $N$. imbricatus, the aperture opens intracranially in the transverse sinus, and this would link the opening with the venous system. A similar relationship was recorded for other notoungulates (e.g., Paedotherium and Cochilius) discovered with detailed micro-CT images (MacPhee 2014: figs. 9d, $12 \mathrm{e}, 15 \mathrm{~d}$, respectively). However, the petrosal anatomy of a probable Itaboraian notoungulate evidenced the presence of an arteria diploëtica magna (Billet and de Muizon 2013). This suggests homologies of the posterior occipital opening with the posttemporal canal for the passage of the arteria diploëtica magna and accompanying vein (MacPhee 2014). Lateral and dorsal to the depression, the occiput bulges, probably due to the well-developed epitympanic sinus. Those internal cavities were recognized in other toxodontians (Gabbert 2004; MacPhee 2014). 

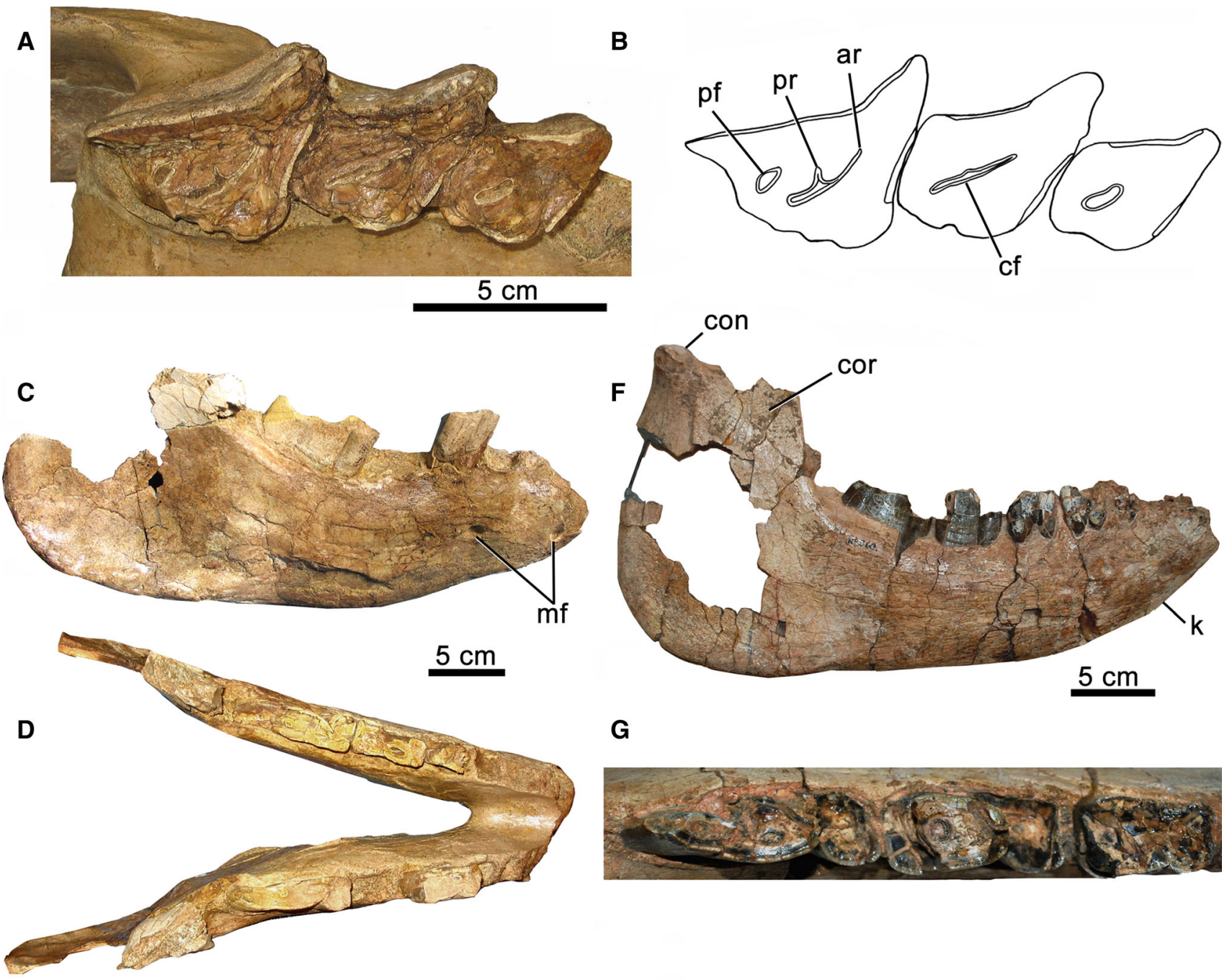

G
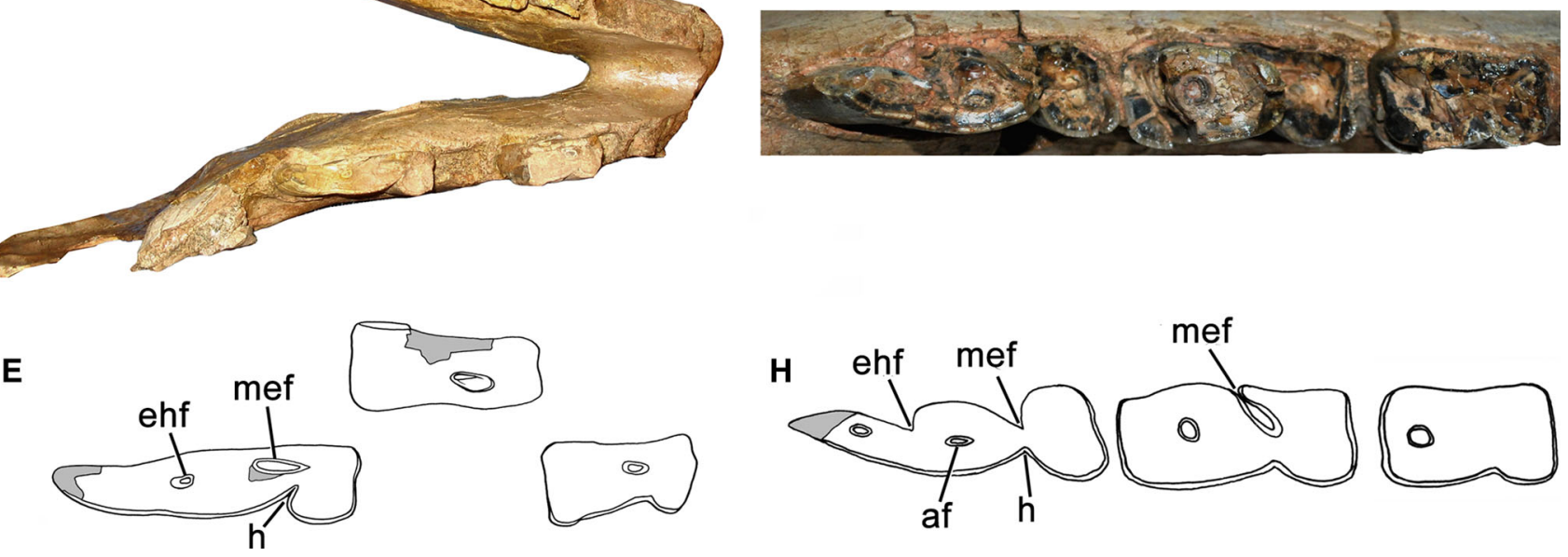

Fig. 7 Upper dentition of Nesodon taweretus sp. nov. and dentaries tentatively assigned to it. MHNSR-PV 1004, right maxilla with M1M3 in occlusal view (a, b). MHNSR-PV 1000, lower jaw in lateral (c) and occlusal view (d), and detail of left $\mathrm{m} 2$, and right $\mathrm{m} 1$ and $\mathrm{m} 3$ (e) (not to scale). MHNSR-PV 360, lower jaw in lateral view (f) and

detail of $\mathrm{m} 1-\mathrm{m} 3$ in occlusal view (g, h) (not to scale). af Accessory fossettid, con mandibular condyle, cor coronoid process, ehf entohypoconid fold or fossettid, $h$ hypoflexid, $k$ median symphyseal labial keel, mef meta-entoconid fold or fossettid, $m f$ mental foramen

\section{Upper dentition}

The dental formula of the skull is I1-3 C1 P1-4 M1-3, as in other toxodontids (Scott 1912; Madden 1997). The anterior alveoli are tightly packed and lack diastemata between I2I3 and $\mathrm{C}$, which are present in $N$. imbricatus. Molars are moderately imbricated. The size increases rapidly from M1

to M3 (Fig. 7a, b). The layer of enamel covers the labial and anterolingual surfaces of the teeth. The occlusal outline is slightly anterolabial-posterolingually elongated. The original Y-shaped lingual fold is lost with wear, isolating a central fossette. It is ovoid and rather reduced in M1, but much longer and narrower in M2-M3. In the M3, the $\mathrm{Y}$-shape is still visible in the fossette, with a long anterior 
ramus and a short posterior one. The M3 also has a postfossette and a shallow lingual groove limiting the protocone. The ectoloph is more concave at its anterior third.

Comparing with other Miocene toxodontids, the molars of MHNSR-PV 1004 are much larger than those of Adinotherium and about the same size as those of $\mathrm{N}$. imbricatus. Adinotherium has molars with a straighter ectoloph and more complicated occlusal morphology than $N$. taweretus, and there are diastemata between I3-C-P1 (Scott 1912). The molars of $N$. taweretus have less persistent folds and fossettes than those of $N$. imbricatus, which in extremely worn molars still show the posterior ramus of the lingual fold. All three taxa show closed fossettes by the confluence of protoloph and metaloph in adults (Scott 1912; Pascual 1954). In contrast, Palyeidodon (ESM 2), with projected protoloph and reduced metaloph forming lingual columns, and Hyperoxotodon, with more elongated molars and without postfossette (Roth 1899; Kraglievich 1930; Cabrera and Kraglievich 1931; Madden 1990, 1997), show that the lingual fold remains open.

Mandible and lower dentition

\section{Mandible}

Four toxodontid mandibular fragments that were recovered from the Aisol Formation proved difficult to assign taxonomically. MHNSR-PV 1001 is larger than the other three mandibular fragments and MHNSR-PV 1075 is more suitable to Palyeidodon than Nesodon (ESM 2). We provisionally assign MHNSR-PV 1000 and MHNSR-PV 360 to Nesodon, and MHNSR-PV 1001 and MHNSR-PV 1075 to Palyeidodon, with the following comparative description outlining these assignations.

MHNSR-PV 1000 is an incomplete mandible lacking the anterior part of the symphysis and the vertical ramus (Fig. 7c, d). The teeth have advanced wear, comparable to that of the upper teeth in the skull and corresponding to a more aged individual than MHNSR-PV 360. The horizontal ramus is robust.

The ventral border is convex (less evident in MHNSRPV 360 at the level of $\mathrm{m} 2-\mathrm{m} 3$ ). The posteroventral inflexion of the dentary shown in N. imbricatus (Scott 1912: pl. 13) is absent in MHNSR-PV 1000 and very shallow in MHNSR-PV 360. The symphysis is fused and lacks any vestiges of the suture. It extends back to the level of p4-m1 embrasure in MHNSR-PV 1000 or to the level of p4 in MHNSR-PV 360. Both morphologies were observed in specimens of $N$. imbricatus, which was related to the large individual variations in the extension of the mandibular symphysis observed for this species (Scott 1912: 187). Both specimens have two mental foramina in lateral view and one additional foramen in anterior view and below i3. An interesting feature preserved in MHNSR-PV 360 is a thin, median symphyseal labial keel below the alveolar border. This area is not preserved in the remaining specimens from the Aisol Formation and therefore it is not comparable. A low median symphyseal keel is present in N. imbricatus, Xotodon, and Calchaquitherium (Nassif et al. 2000).

The specimen MHNSR-PV 1075 assigned to Palyeidodon (ESM 2) shows a higher vertical ramus than MHNSRPV 360, with its posterior border more projected backward from the condyle. The ventral border of the horizontal ramus is straighter than in MHNSR-PV 1000 and MHNSRPV 360. Both features are observed on the holotype of Palyeidodon obtusum (Madden 1990: 155, fig. 29b).

\section{Lower dentition}

Lower molars of MHNSR-PV 1000 (Fig. 7e) present a wide, labially convex trigonid; they have meta-entoconid and ento-hypoconid fossettids. The latter is small and has almost disappeared in $\mathrm{m} 2$. The $\mathrm{m} 1$ is wider at the occlusal surface than at the alveolar level. The hypoflexid is deeper in $\mathrm{m} 3$.

The preserved molars in MHNSR-PV 360 (Fig. 7g, h) show some differences in $\mathrm{m} 3$ from that of MHNSR-PV 1000. This molar has two main lingual folds that are largely open and, as a consequence, meta-entoconid and entohypoconid fossettids are not yet formed (the meta-entoconid fold is still barely open in $\mathrm{m} 2$ ). Instead, two other fossettids are well defined: one close to the labial wall and centrally placed in the talonid, equivalent to the accessory fossettid defined by Madden (1990), and another is posteriorly placed (Fig. 7h). The accessory fossettid is commonly present in Nesodon (Scott 1912) but is absent in Palyeidodon (Madden 1990), which supports the view that MHNSR-PV 360 belongs to the new species of Nesodon. However, the specimen MHNSR-PV 1075 assigned to Palyeidodon (ESM 2) has a small accessory fossettid in $\mathrm{m} 3$. Given the difference between the vertical and horizontal rami of these two specimens, having accessory fossettids could reflect a variable character in Palyeidodon.

\section{Postcranium}

Among the abundant isolated postcranial elements from the Aisol Formation (Forasiepi et al. 2011), a distal fragment of the left femur (MHNSR-PV 122) and three ulnae (MHNSR-PV 1008, MHNSR-PV 1009, and MHNSR-PV 1010) are tentatively assigned to the new species.

The femur is massive and anteroposteriorly thick (Fig. 8a, b). The trochlea is shallow, irregular in shape, with the medial border taller than the lateral. A blunt 

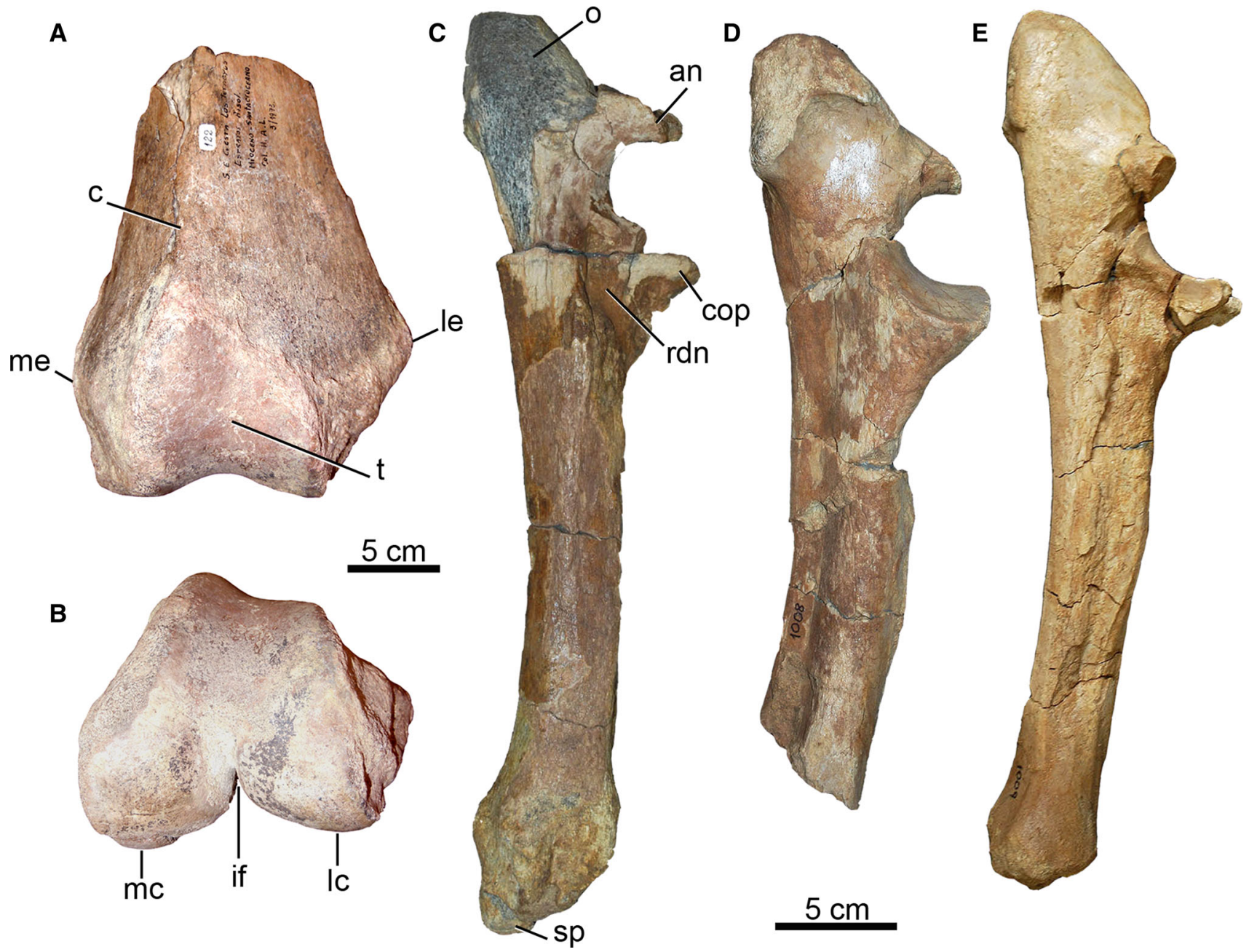

Fig. 8 Postcranium tentatively assigned to Nesodon taweretus sp. nov. MHNSR-PV 122, distal fragment of left femur in anterior (a) and distal views (b). MHNSR-PV 1010, left ulna in medial view (c). MHNSR-PV 1008, right ulna in lateral view (d). MHNSR-PV 1009,

left ulna in medial view (e). an Anconeal process, $c$ crest, cop coronoid process, if intertrochanteric fossa, lc lateral condyle, le lateral epicondyle, $m c$ medial condyle, me medial epicondyle, $o$ olecranon, $r d n$ radial notch, $s p$ styloid process, $t$ trochlea

vertical crest develops on the diaphysis from the medial border of the trochlea. The lateral epicondyle is more robust and protruded than the medial epicondyle. In posterior view, the medial condyle is narrower, taller, and more posteriorly projected than the lateral condyle. The intertrochanteric fossa is narrow and very deep.

The ulna is robust and slightly posteriorly curved (Fig. 8c-e). MHNSR-PV 1009 is smaller and more slender than the other two, probably due to ontogenetic differences. It lacks the distal epiphysis, indicating that it was not completely ossified, therefore corresponding to a juvenile. The olecranon is robust, laterally concave, and long. Its proximal surface has deep scars, suggesting a strong triceps musculature. The articular area for the humerus is deep and surrounded by protruding anconeal and medial coronoid processes. The radial facet is concave and medially faced. The diaphysis is lateromedially compressed in MHNSR-
PV 1008 and MHNSR-PV 1009, whereas it is more circular in section in MHNSR-PV 1010 and strengthened by vertical crests on its medial and lateral sides. The distal epiphysis is preserved only in MHNSR-PV 1010 (Fig. 8c). The styloid process is distolaterally projected and has a convex articular facet.

\section{Bone histology}

The three ulnae were sampled for histological analysis (Fig. 9a-d). The bone samples are characterized by a compact cortex and a dense network of fine trabeculae in the medullary region. The tissue of the cortex is well vascularized by mostly longitudinally oriented vascular canals. Also, very few irregularly oriented canals can be found. The vascular canals are arranged randomly. Osteocyte lacunae are large and very abundant (Fig. 9a). The 

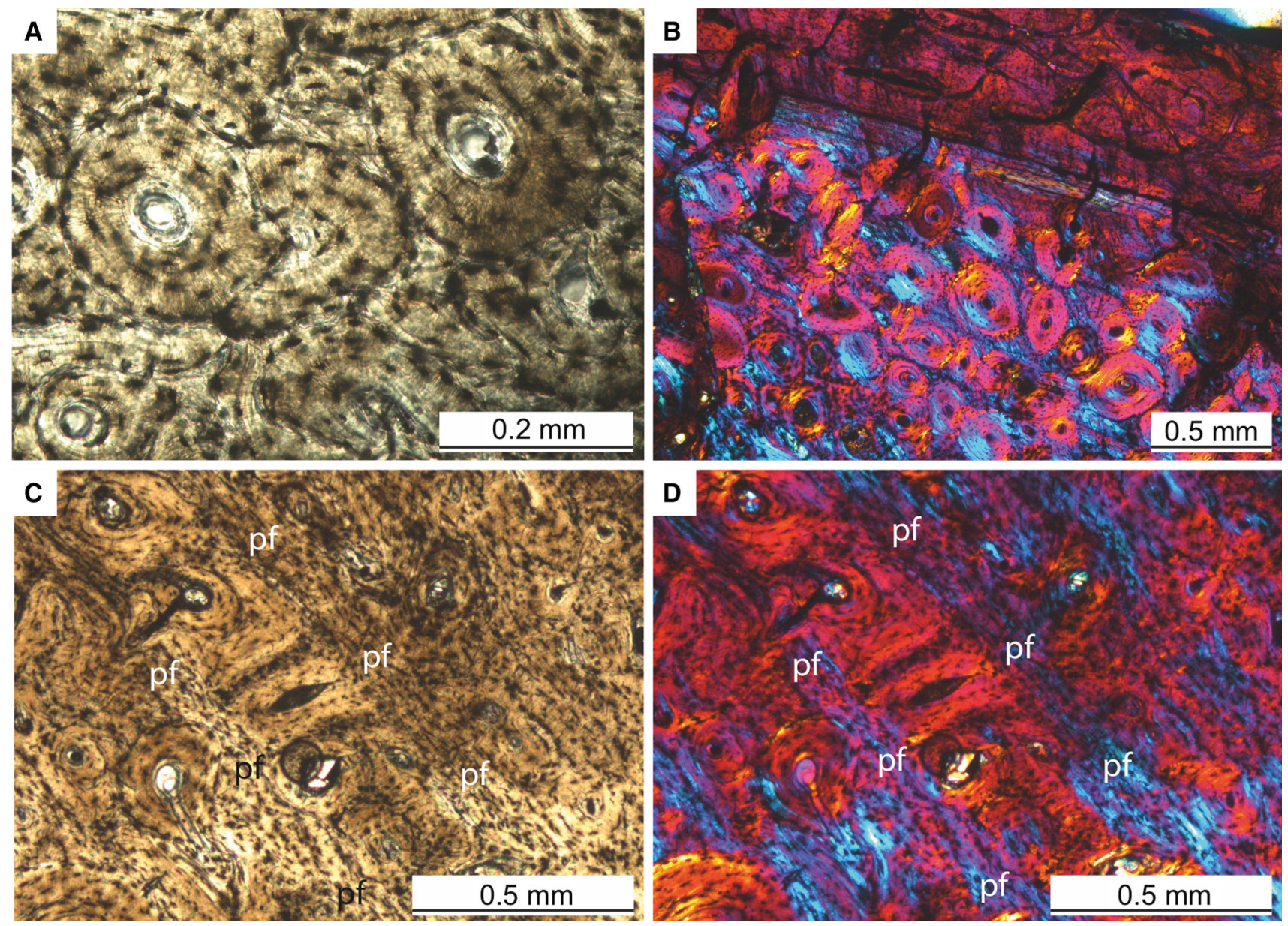

Fig. 9 Histological details of the ulnae. a Detail of secondarily remodeled bone tissue of MHNSR-PV 1010, showing the large and abundant osteocyte lacunae (dark spots). b Contrast of the parallel-fibered primary outer layer of bone tissue (upper third of picture) with the heavily remodeled inner cortex in MHNSR-PV 1010. c, d Detail of the anterior side of the cortex of MHNSR-PV 1008, showing a laminar organization. Two of a total of four circumferential lines of parallel-fibered tissue $(p f)$ are shown here

cortices of the three ulnae are all heavily remodeled. Areas of primary bone matrix are visible between secondary osteons, which suggest a mostly parallel-fibered to lamellar organization of the tissue with elongated and flattened osteocyte lacunae (Fig. 9b). Bundles of fibers are arranged randomly. Localized areas of woven bone characterized by round osteocyte lacunae are also found. The most external layer of the cortex with parallel fibers is partially preserved in MHNSR-PV 1008 and MHNSR-PV 1010. It contains only very few secondary osteons and clearly contrasts with the heavily remodeled inner cortex (Fig. 9b). The anterior portion of the cortex of MHNSR-PV 1008 additionally shows some laminar organization, and four circumferential lines of parallel-fibered bone tissue can be made out in the remodeled primary matrix (Fig. 9c, d). These lines do not represent lines of arrested growth (LAGs). The layer of bone lining the medullary cavity and the trabeculae show lamellar tissue organization.

\section{Discussion}

Polanski (Dessanti 1954, 1956; González Díaz 1972) identified Nesodon imbricatus in the deposits of the Aisol Formation but, unfortunately, the material was not figured and is now missing from the collections (Soria 1983). The preceding comparative description makes it evident that MHNSR-PV 1004 presents clear similarities with the genus Nesodon. MHNSR-PV 1004 is conspicuously larger than Adinotherium (see below; Fig. 10) with a very shallow or an absent angled posteroventral border of the mandible. It differs from Palyeidodon in an unreduced sagittal crest, the presence of a postfossette in M3, the isolation of primary lingual fold as fossette in later wear stages in M2 and M3, and the presence of accessory fossettids in lower molars (revised diagnosis of Nesodon in Croft et al. 2004). There are some noticeable cranial differences with respect to $N$. imbricatus and other Nesodon species (e.g., $N$. 
Table 1 Measurements of Nesodon taweretus sp. nov. from holotype and tentatively referred material from the Aisol Formation. The measurements used for body mass estimation (ESM 2) are shown with abbreviations in parentheses

\begin{tabular}{|c|c|c|c|c|}
\hline \multicolumn{4}{|l|}{ Skull } & MHNSR-PV 1004 \\
\hline Total skull length (TSL) & & & & 440 \\
\hline Posterior skull length $(\mathrm{PSL}=\mathrm{SC})$ & & & & 187 \\
\hline Premaxillary height, middle line & & & & $\sim 53.5$ \\
\hline Muzzle (premaxilla-nasal) height & & & & $\sim 129$ \\
\hline Muzzle width (MZW) & & & & 60.5 \\
\hline Palatal width, level of P1 & & & & 36 \\
\hline Palatal width, level of M1 & & & & 63 \\
\hline Palatal width, level of M2 (PAW) & & & & 75 \\
\hline Palatal width, level of M3 & & & & 76.2 \\
\hline Frontal width at postorbital processes & & & & 141.7 \\
\hline Depth of the face under the orbit (SD) & & & & 110 \\
\hline Anterior nasal width & & & & 74.2 \\
\hline Premaxilla-orbit length & & & & 210 \\
\hline Nasal aperture-nuchal crest length & & & & 354.5 \\
\hline Nasal aperture-orbit length & & & & 167 \\
\hline Length of the ridge for the origin of masseter (SA) & & & & 129 \\
\hline Occipital width & & & & $\sim 211.5$ \\
\hline Occipital height $(\mathrm{OCH}=\mathrm{SB})$ & & & & 138 \\
\hline Length of the paraoccipital process (SE) & & & & 80 \\
\hline Nuchal crest-foramen magnum height & & & & 88.5 \\
\hline Foramen magnum & & & & $26 \times 42$ \\
\hline Basicranial length (BL) & & & & 175.5 \\
\hline Tip of nasal-occipital crest length & & & & 343.2 \\
\hline Sagittal crest length & & & & 55.5 \\
\hline Zygomatic arch maximum height & & & & 82 \\
\hline Zygomatic arch posterior height & & & & 47.9 \\
\hline Length M1-M3 & & & & 125.7 \\
\hline Length I1-M3 (broken area of I1 alveoli) & & & & $\sim 266.3$ \\
\hline Length P1-M3 (alveoli P) & & & & $\sim 199.4$ \\
\hline Length P1-P4 (alveoli) & & & & $\sim 79.2$ \\
\hline Mandible & MHNSR-PV 360 & MHNSR-PV 1075 & MHNSR-PV 1000 & MHNSR-PV 100 \\
\hline Total jaw length (TJL) & $\sim 340$ & - & $\sim 360$ & - \\
\hline Symphyseal length & 66.0 & - & - & - \\
\hline Posterior jaw length (JMA) & 107.5 & - & - & - \\
\hline Height of the horizontal ramus at the level of p4 (labial view) & 65.0 & 65.0 & 75.0 & - \\
\hline Height of the horizontal ramus at the level of $\mathrm{m} 3$ (labial view) & 99.0 & 106 & 104 & 132 \\
\hline Mandible width at the level of $\mathrm{p} 4$ & 23.0 & 29.0 & 30.00 & - \\
\hline Mandible width at the level of $\mathrm{m} 3$ & 29.5 & 28.0 & 36.0 & 32.0 \\
\hline Height from ventral border of the horizontal ramus to condyle & 170 & 220 & - & - \\
\hline Width of the condyle & $\sim 36$ & 50.0 & - & - \\
\hline Lower molar tooth row length & 119.8 & 132.2 & 136.4 & - \\
\hline Upper dentition & & & & MHNSR PV 1004 \\
\hline M1 L & & & & 35.2 \\
\hline M1 W & & & & 28.2 \\
\hline M2 L & & & & 42.6 \\
\hline
\end{tabular}


Table 1 continued

\begin{tabular}{llllll}
\hline Upper dentition & & & & & MHNSR PV 1004 \\
\hline M2 W & & & & 33.9 \\
M3 L & & & 60.0 & 37.7 \\
M3 W & & & & \\
\hline Lower dentition & MHNSR-PV 1000 (right side) & MHNSR-PV 1000 (left side) & MHNSR-PV 360 & MHNSR-PV 1075 & MHNSR-PV 1001 \\
\hline p4 L & $\sim 35$ & $\sim 35$ & $\sim 23$ & 25 & - \\
p4 W & $\sim 18$ alveolar size & $\sim 18$ alveolar size & - & - & - \\
m1 L & 33.0 & $\sim 31$ & 28.0 & 33.0 & - \\
m1 Wa & 18.0 & - & 15.0 & - & - \\
m1 Wp & 18.6 & - & 16.0 & 17.0 & - \\
m2 L & $\sim 34$ & 40.0 & 36.0 & 40.0 & - \\
m2 Wa & - & - & 15.6 & 17.3 & - \\
m2 Wp & - & 18.0 & 15.5 & 17.0 & - \\
m3 L & 68.0 & $\sim 66$ & 51.0 & 50.0 & \\
m3 Wa & 20.0 & 21.0 & 16.0 & 16.0 & 19.0 \\
m3 Wp & 15.7 & 16.5 & 12.7 & 12.8 & 16.0 \\
\hline
\end{tabular}

Fig. 10 Bivariate plot of lower molar dimensions of Nesodon and Adinotherium (modified from Croft et al. 2004)

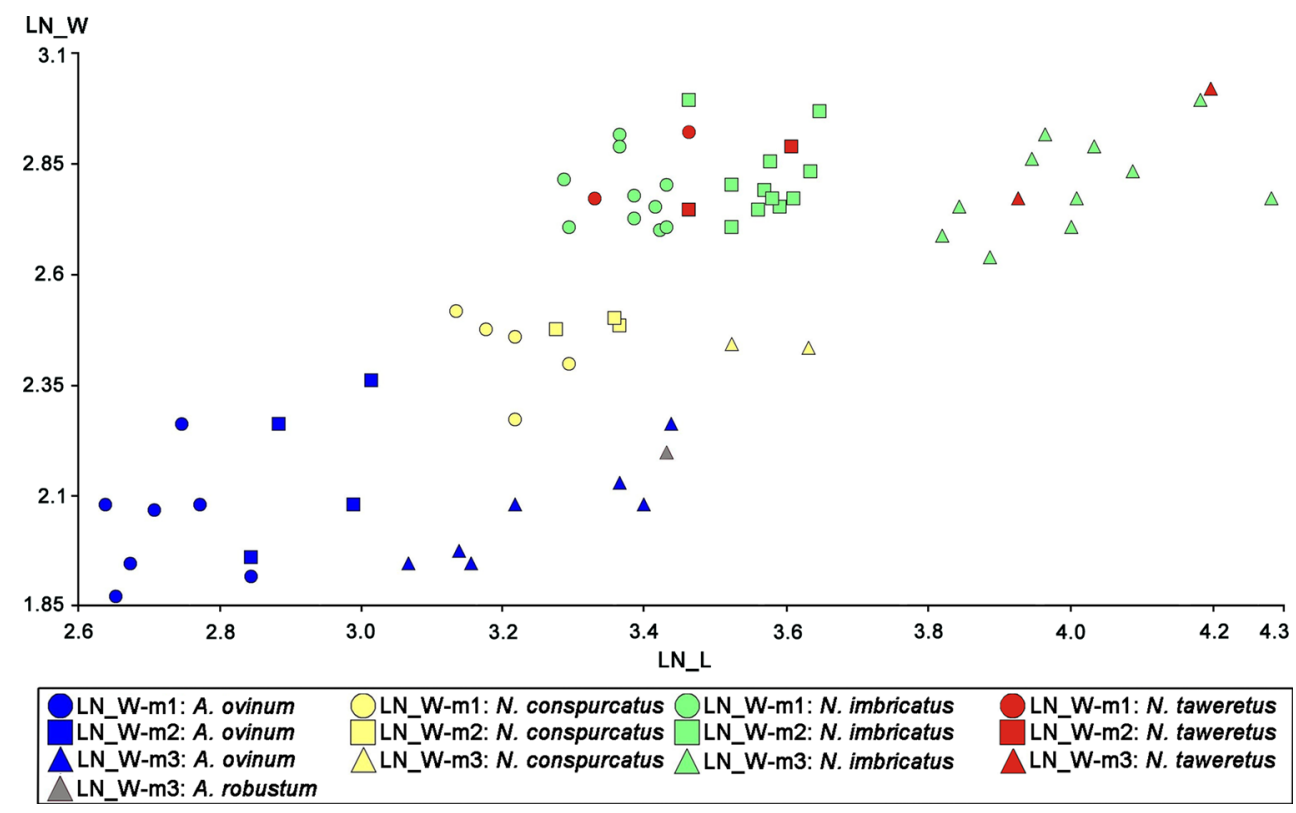

conspurcatus), which are interpreted as being of specific significance.

To compare Nesodon taweretus sp. nov. with other nesodontines, measurements of the lower dentition of specimens MHNSR-PV 360 and PV 1000 were added to the bivariate plot presented by Croft et al. (2004: fig. 3) and reproduced in Fig. 10. It shows that the $\mathrm{m} 1$ of MHNSR-PV 1000 exceeds the size of $N$. imbricatus, while that of MHNSR-PV 360 falls within the range of this species; a similar situation occurs with $\mathrm{m} 2$. The $\mathrm{m} 3$ of MHNSR-PV 360 is wider than the specimens of
$N$. imbricatus, and the other $\mathrm{m} 3$ has a similar size to the rest of the sample. Therefore, dental measurements of $N$. taweretus sp. nov are similar to those of $N$. imbricatus, but they are clearly larger than those of $N$. conspurcatus and Adinotherium ovinum.

The body mass of Nesodon taweretus sp. nov. was estimated as about $550 \mathrm{~kg}$, using the average of the results obtained using different algorithms (4.1, 4.2, 4.3, and 5.1 from Mendoza et al. 2006) and equations (TSL, OCH, SLML, PSL, and TJL from Janis 1990) following Cassini et al. (2012, tables 14.1 and 14.2; ESM 2). The weighted 


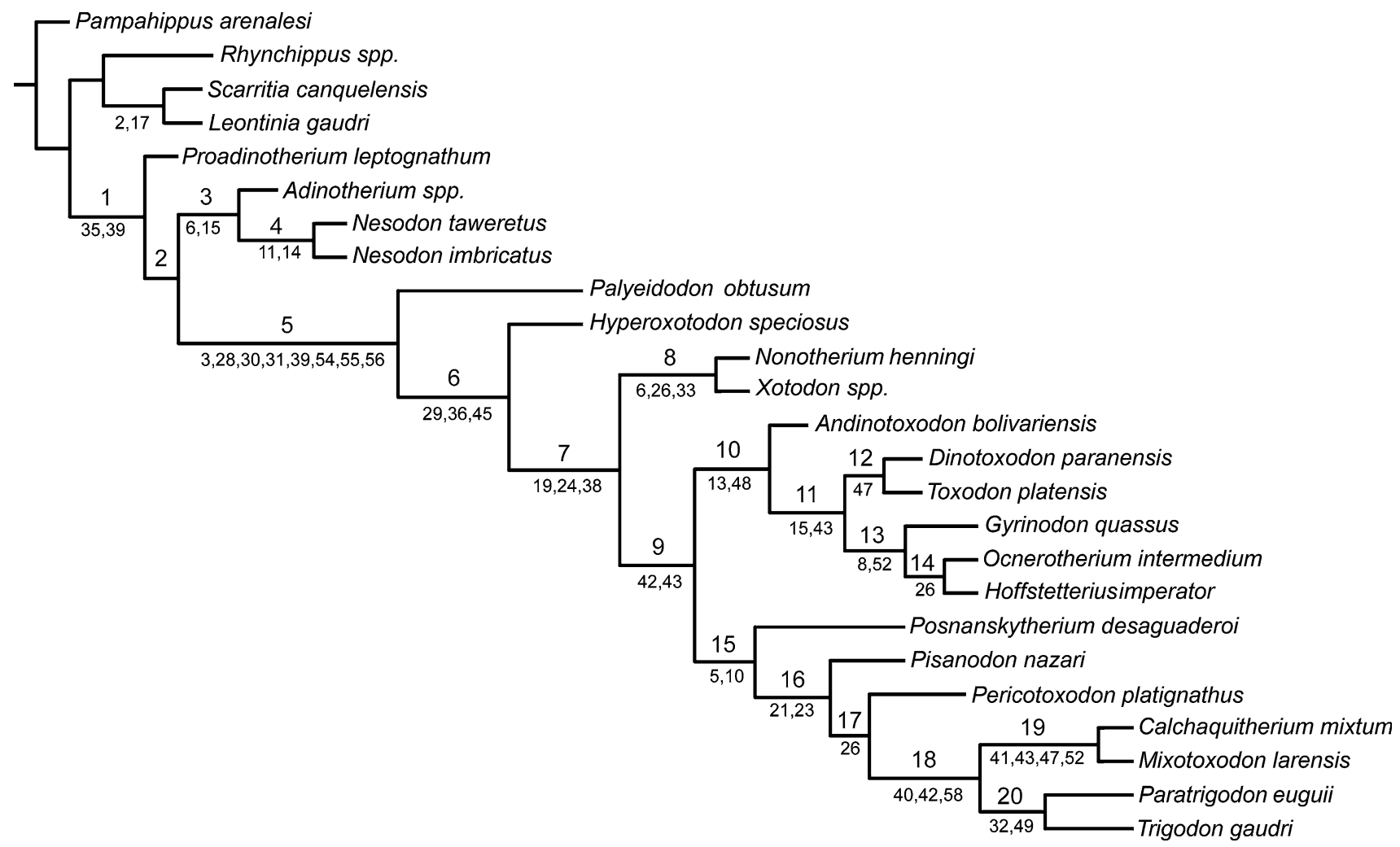

Fig. 11 Phylogenetic relationships of Toxodontidae derived from the analysis performed under implied weights $(K=3)$

mean of Janis's equations (which includes the percent prediction error in the estimation) provides a slightly larger value of about $570 \mathrm{~kg}$. Both estimations yield similar values. The estimated body mass for $N$. taweretus sp. nov. is similar to that for $N$. imbricatus (around $640 \mathrm{~kg}$; range between 500 and $800 \mathrm{~kg}$; Cassini et al. 2012).

Studies of bone histology are infrequent for notoungulates, and this study contains detailed information and analysis for further work and comparison. The histology of the ulnae tentatively assigned to $N$. taweretus $\mathrm{sp}$. nov. is in accordance with the structure described for Toxodon and Mesotherium (as Typotherium; de Ricqlès et al. 2009) and more generally for eutherian mammals (Hurum and Chinsamy-Turan 2012), and suggests a decrease in growth rate during ontogeny. Remodeling is a great factor in $N$. taweretus sp. nov., which is a common feature in mammalian bones (Enlow and Brown 1958)-particularly in large taxa, probably due to increased loading (Straehl et al. 2013).

Phylogenetic analysis

A parsimony analysis was performed based on 25 taxa and 59 morphological cranial and dental characters (ESM 2) modified from the matrix presented by Nassif et al. (2000).
Taxa included four outgroups (two Notohippidae and two Leontiniidae; alternatively see Cerdeño and Vera 2010 for the phylogenetic support for these families) and 21 Toxodontidae.

Some codifications were modified from the contribution of Nassif et al. (2000). A low median symphyseal keel is present in $N$. imbricatus and $N$. taweretus sp. nov. [character 14 (1)]. A new revision of the material referred to Trigodon indicates that the lingual enamel in $\mathrm{m} 1$ is placed between the anterior fold and the hypoconulid, without covering the lingual face of the hypoconulid completely [character 54 (1)]. The specimen MHNSR-PV 1075 here assigned to Palyeidodon reveals variation in the presence of accessory fossettids in lower molars [character 46 ( 0 and 1)]. New studies in Dinotoxodon (Schmidt 2013) allowed us to complete the codifications for the characters 27,30 , 43-48, and 54-56 and to modify others as follows: the horizontal ramus may or may not have a ventral extension [character 8 (0 and 1)]; the upper molars have a median crista and an incipient Y-shaped median valley [character 29 (0)]; and the lingual enamel on M3 covers only the posterior groove [character 32 (2)].

The data matrix (ESM 2) was analyzed using maximum parsimony with equally weighted characters and under implied weighting with the computer program TNT 1.1 
(Goloboff et al. 2008b). All characters were treated as nonadditive. Equally weighted parsimony analysis was conducted performing a heuristic search of Wagner trees with 500 random addition sequences, followed by TBR (tree bisection reconnection), and saving 20 trees per round, which improves the searches and ensures that all optimal trees are found. The program provided the 16 most parsimonious topologies of 183 steps, with a consistency index $(\mathrm{CI})$ of 0.46 and a retention index (RI) of 0.65. The strict consensus and Bremer index of each node are shown in ESM 2.

Analysis performed under implied weighting $(K=3)$ provided one tree (Fig. 11). This method uses evidence of homoplasy to estimate character reliability and finds trees with the maximum total fit (optimal topologies) (Goloboff 1993; Goloboff et al. 2008a). The trees constructed under implied weighting have the most reliable characters (Goloboff 1993). The topologies of the consensus from the analysis under equally weighted characters and the tree obtained under implied weights were in general agreement. Monophyly of the major groups (Toxodontidae, Nesodontinae, Toxodontinae) is supported in both analyses. Differences are in the positions of some toxodontines and consequently the re-arrangement of some parts of the tree. The clade comprising Calchaquitherium, Nonotherium, and Xotodon that is found with equally weighted characters (ESM 2), as in the analysis by Nassif et al. (2000), is reorganized under implied weighting, mainly due to the different positions of Calchaquiterium (Fig. 11). We base the discussion on the tree topology and the supporting node characters with the tree obtained under implied weighting because it is better resolved and the characters have been demonstrated to be more reliable than equally weighted characters are (Goloboff 1993; Goloboff et al. 2008a). The tree obtained (Fig. 11) is compared with previous phylogenetic results (Nassif et al. 2000).

The monophyly of the Toxodontidae is supported by two synapomorphies (node 1): i1 triangular in section [35 (1)], and the enamel on the lingual side of i3 being narrower than on the labial side [39 (3)]. The nesodontines consist of Nesodon and Adinotherium, with Proadinotherium as the sister group of the remaining toxodontids; node 2 is supported by any synapomorphy. In node 3, Adinotherium and Nesodon share a sigmoid zygomatic arch [6 (1)] and symphysis without a well-differentiated chin angle [15 (0)]. Nesodon taweretus sp. nov. forms a monophyletic group (node 4) with $N$. imbricatus sharing a rounded postero-ventral border of the vertical ramus [11 (0)] and the symphysis with a median labial keel [14 (1)]. This result supports the generic determination of the new species. Node 5 is supported by eight synapomorphies: [3 (1)], [28 (1)], [30 (1)], [31 (1)], [39 (1)], [54 (1)], [55 (1)], and [56 (1)], and includes all toxodontines (sensu Nassif et al. 2000). The first divergence corresponds to Palyeidodon, followed by Hyperoxotodon (node 6). Node 7 groups the remaining taxa with three synapomorphies: a triangular and buccolingually flattened cross-section of I1 [19 (4)], P2 without groove or fossette [24 (1)], and an absence of lingual enamel in $\mathrm{i} 1-\mathrm{i} 2$ [38 (2)]. This group splits into two clades. The first is formed by Nonotherium and Xotodon (node 8), which share a sigmoid zygomatic arch [6 (1)], P3-P4 without a groove or fossette [26 (1)], and very concave ectoloph of the molars [33 (1)]. The second, major clade (node 9) is supported by two synapomorphies: p1 absent [42 (2)] and reduced lingual enamel of p2-p4 [43 (1)], and gathers two large groups. One group is formed by [Andinotoxodon ((Dinotoxodon Toxodon) (Gyrinodon (Ocnerotherium Hoffstetterius)))] and is supported by two synapomorphies (node 10): alveolar border of the symphysis straighter [13 (1)] and anterior fold (paraconidmetaconid) of $\mathrm{m} 1-\mathrm{m} 2$ at the same level as the buccal fold [48 (1)]. The other clade (node 15) is composed of seven taxa which share infraorbital foramen close to the zygomatic apophysis of the maxilla [5 (0)] and coronoid apophyses and condyles convergent [10 (1)]. Within this large clade, Posnanskytherium, Pisanodon, and Pericotoxodon appear as successive basal taxa (nodes 15, 16, and 17 , respectively), and as sister taxa of two small monophyletic groups supported by three synapomorphies (node 18: [40 (1)], [42 (1)], [58 (1)]). One group is composed of Calchaquitherium and Mixotoxodon (node 19: [41 (0)], [43 (2)], [47 (0)], [52 (1)] and the other by Paratrigodon and Trigodon (node 20: [32 (1)] and [49 (1)]).

The topology obtained (Fig. 11) differs from that in Nassif et al. (2000) mainly in the arrangement of the Toxodontinae (node 7). Some clades such as (Nonotherium and Xotodon), (Ocnerotherium and Hoffstetterius), and (Paratrigodon and Trigodon) are recovered in both analyses but their positions are different within the cladogram. Moreover, Dinotoxodon appears as sister taxon of Toxodon (Fig. 11, node 12), sharing a well-developed anterior fold in $\mathrm{m} 1-\mathrm{m} 2$ ([47 (0)]), in contrast to the results in Nassif et al. (2000), where Dinotoxodon is related to Pericotoxodon, and Toxodon to Andinotoxodon.

\section{Final remarks}

The vertebrate association from the Aisol Formation includes anurans, turtles, carnivorous birds, and a large set of mammals (Soria 1983; Forasiepi et al. 2011). These preliminary studies did not provide precise taxonomic determinations, and initially suggested affinities with associations from the Middle Miocene of Patagonia (Soria 1983; Forasiepi et al. 2011). Among toxodontids, Palyeidodon cf. P. obtusum would relate the Aisol Formation to the Collón Curá and Río Frías formations (Roth 1899; 
Pascual 1954; Madden 1990). The presence of cf. Palyeidodon was suggested for the extrapatagonian Santacrucian locality of Chucal, Chile (Bond and García 2002), which is older than 17.5 Ma (Croft et al. 2007), based on poorly preserved material. If this find is correct, the presence of Palyeidodon in late Early Miocene outcrops may not be surprising, but this assignation was questioned (Croft et al. 2004, 2009) and should be considered quite tentative. The recognition of the genus Nesodon suggests that the vertebrate association from Aisol is no older than Santacrucian, although the new species $N$. taweretus differentiates the Aisol assemblage from the other Santacrucian faunas. Other mammals from Aisol are not conclusive in determining the age.

$\mathrm{U}-\mathrm{Pb}$ zircon dating of the tuff sample from the base of the Aisol Formation suggests a late Early Miocene age of $19.480 \pm 0.025 \mathrm{Ma}$ (Burdigalian). A similar accuracy has not yet been established for the top of the sequence. Tectosedimentary evidence from the Andean orogenic basins from south-central Argentina suggests that the sequence may extend to the Langhian, but not younger than that. During the late Burdigalian and early Langhian, a major tectonic event occurred, with a consequent strong angular unconformity in the sedimentary sequences, associated with intense volcanism (Garrido et al. 2012 and literature cited therein). We do not find evidence of this sedimentary hiatus within the Aisol Formation, but a continuous succession including the U-Pb dated tuffs. Consequently, we associate the vertebrate assemblage with the late Early Miocene.

The Santacrucian Age covers the time span between $\sim 18$ and $16 \mathrm{Ma}$ and typically includes outcrops of the Santa Cruz Formation in the eastern region of the Santa Cruz Province on the Atlantic coastal plain (Vizcaíno et al. 2012; Perkins et al. 2012). Slightly older vertebrate associations from the Adean foothills (e.g., Karaike) dated 19-14 Ma (Perkins et al. 2012) are possibly included in the Santacrucian (see discussion in Vizcaíno et al. 2012 and referenced literature). At intermediate South American latitudes, the Santacrucian Age may extend to earlier times considering the mammalian association from Chucal (north Chile) dated at $\sim 19-17 \mathrm{Ma}$ (Croft et al. 2007). Assuming that the absolute dating of ca. 19.5 Ma is correct for the base of the Aisol Formation and that the vertebrate association corresponds to the Santacrucian Age, paleoenvironmental conditions could explain the taxonomic distinction between the Aisol and Santa Cruz formations in southern Patagonia. The large latitudinal separation between both areas would have impacted the different evolutions of the faunas. This hypothesis has already been proposed for the early Oligocene assemblage from Tinguiririca at a similar latitude in Chile (Croft et al. 2008) and the late Oligocene assemblage from Quebrada Fiera in southern Mendoza (Cerdeño et al. 2010; Cerdeño 2011).
Similarly, the Santacrucian assemblage from Chinches (San Juan Province; López et al. 2011) and the Santacrucian assemblage from Chucal (north Chile; Flynn et al. 2002; Croft et al. 2004) are distinguishable from their Patagonian equivalents. Furthermore, analysis of Middle Miocene fossil associations from middle latitudes of Bolivia (Croft et al. 2009) has already suggested an evident latitudinal provincialism that could have begun to develop by at least the Early Miocene, deriving from the Andean orogeny and other paleoenvironmental factors (Croft et al. 2004).

\section{Conclusions}

The present study proposes the existence of a new toxodontid notoungulate in the Aisol Formation (Mendoza, Argentina), recognized as Nesodon taweretus sp. nov.

Nesodon taweretus sp. nov. differs from the other Neosodon species in several cranial and dental features. Close comparisons were made with the Patagonian N. imbricatus, a common toxodontid in the Santa Cruz Formation (Santacrucian Age). N. taweretus was similar in size to $N$. imbricatus, with a body mass of about $550 \mathrm{~kg}$. Phylogenetic analysis supports the assignation of the new species to the genus Nesodon.

A tuff sample from the base of the Aisol Formation provided a high-precision U-Pb zircon age of $19.480 \pm$ $0.025 \mathrm{Ma}$, which places the base of the unit in the late Early Miocene-Burdigalian. The vertebrate association would be included in the Santacrucian Age. Latitudinal separation could explain taxonomic differences, as exhibited by the species of Nesodon found in the Mendoza and Santa Cruz areas.

Acknowledgments We acknowledge two anonymous reviewers for their observations that improved the original manuscript; G. H. Cassini for his valuable assistance in the paleobiological aspects; S. D. Kay for reviewing the English; M. S. de la Fuente and M. R. Sánchez-Villagra for support and suggestions during manuscript preparation; R. D. E. MacPhee for helpful comments on notoungulate anatomy; and J. Blanco for the artistic reconstruction of $N$. taweretus sp. nov in Fig. 1. The Willi Hennig Society provides a free version of the TNT program. This research was financially supported by the project CONICET-PIP 2011-2013 0276.

\section{References}

Billet, G. 2010. New observations on the skull of Pyrotherium (Pyrotheria, Mammalia) and new phylogenetic hypotheses on South American ungulates. Journal of Mammalian Evolution 17: 21-59.

Billet, G., and C. de Muizon. 2013. External and internal anatomy of a petrosal from the late Paleocene of Itaboraí, Brazil, referred to Notoungulata (Placentalia). Journal of Vertebrate Paleontology 33: 455-469.

Bond, M. 1999. Quaternary native ungulates of Southern South America: a synthesis. In Quaternary of South America and 
Antarctic Peninsula, ed. J. Rabassa, and M. Salemme, 77-205. Ushuaia: Centro Austral de Investigaciones Científicas and Universidad Nacional de la Patagonia.

Bond, M., and M. García. 2002. Nuevos restos de toxodonte (Mammalia, Notoungulata) en estratos de la Formación Chucal, Mioceno, Altiplano de Arica, norte de Chile. Revista Geológica de Chile 29: 81-91.

Bond, M., E. Cerdeño, and G. López. 1995. Los ungulados nativos de América del Sur. In Evolución Biológica y Climática de la Región Pampeana durante los últimos Cinco Millones de Años. Un Ensayo de Correlación con el Mediterráneo Occidental, ed. M.T. Alberdi, G. Leone, and E.P. Tonni, 259-275. Madrid: Monografías del MNCN, CSIC.

Cabrera, A., and L. Kraglievich. 1931. Diagnosis previas de los ungulados fósiles del Arroyo Chasicó. Notas Preliminares del Museo de La Plata 1: 107-113.

Campbell Jr, K.E. 2004. The Paleogene mammalian fauna of Santa Rosa, Amazonian Perú. Natural History Museum of Los Angeles County, Sciences Series 40: 1-163.

Cassini, G.H., E. Cerdeño, A.L. Villafañe, and N.A. Muñoz. 2012. Paleobiology of Santacrucian native ungulates (Meridiungulata: Astrapotheria, Litopterna, and Notoungulata). In Early Miocene Paleobiology in Patagonia: High-latitude Paleocommunities of the Santa Cruz Formation, ed. S.F. Vizcaíno, R.F. Kay, and M.S. Bargo, 243-286. Cambridge: Cambridge University Press.

Cerdeño, E. 2011. Quebrada Fiera (Mendoza), an important paleobiogeographic center in the South American late Oligocene. Estudios Geológicos 67: 375-384.

Cerdeño, E., and B. Vera. 2010. Mendozahippus fierensis gen. et sp. nov., new Notohippidae (Notoungulata) from the late Oligocene of Mendoza (Argentina). Journal of Vertebrate Paleontology 30: $1805-1817$.

Cerdeño, E., M. Reguero, and B. Vera. 2010. Deseadan Archaeohyracidae (Notoungulata) from Quebrada Fiera (Mendoza, Argentina) in the paleobiogeographic context of the South American late Oligocene. Journal of Paleontology 84: 1177-1187.

Christiansen, P., and J.M. Harris. 2005. Body size of Smilodon (Mammalia: Felidae). Journal of Morphology 266: 369-384.

Cifelli, R.L. 1985. South American ungulate evolution and extinction. In The great American biotic interchange, ed. F.G. Stehli, and S.D. Webb, 249-266. New York: Plenum Press.

Condon D., B. Schoene, S. Bowring, R. Parrish, N. McLean, S. Noble and Q. Crowley. 2007. EARTHTIME; isotopic tracers and optimized solutions for high-precision U-Pb ID-TIMS geochronology. Eos, Transactions, American Geophysical Union, 88.

Croft, D.A. 2007. The middle Miocene (Laventan) Quebrada Honda fauna, Southern Bolivia and a description of its notoungulates. Palaeontology 50: 277-303.

Croft, D.A., J.P. Radic, E. Zurita, R. Charrier, J.J. Flynn, and A.R. Wyss. 2003. A Miocene toxodontid (Mammalia: Notoungulata) from the sedimentary series of the Cura-Mallin Formation, Lonquimay, Chile. Revista Geológica de Chile 30: 285-298.

Croft, D.A., J.J. Flynn, and A.R. Wyss. 2004. Notoungulata and Litopterna of the early Miocene Chucal Fauna, northern Chile. Fieldiana Geology (new series) 50: 1-49.

Croft, D.A., J.J. Flynn, and A.R. Wyss. 2007. A new basal glyptodontid and other Xenarthra of the early Miocene Chucal Fauna, northern Chile. Journal of Vertebrate Paleontology 27: 781-797.

Croft, D.A., J.J. Flynn, and A.R. Wyss. 2008. The Tinguiririca fauna of Chile and the early stages of "modernization" of South American mammal faunas. Arquivos do Museu Nacional, Rio de Janeiro 66: 191-211.

Croft, D.A., F. Anaya, D. Auerbach, C. Garzione, and B.J. MacFadden. 2009. New data on Miocene Neotropical provinciality from Cerdas, Bolivia. Journal of Mammalian Evolution 16: 175-198.

de Ricqlès, A., P. Taquet, and V. de Buffrenil. 2009. "Rediscovery" of Paul Gervais' paleohistological collection. Geodiversitas 31: 943-971.

Davydov, V.I., J.L. Crowley, M.D. Schmitz, and V.I. Poletaev. 2010. High-precision $\mathrm{U}-\mathrm{Pb}$ zircon age calibration of the global Carboniferous time scale and Milankovitch-band cyclicity in the Donets Basin, eastern Ukraine. Geochemistry, Geophysics, Geosystems 11: Q0AA04. doi:10.1029/2009GC002736.

Dessanti, R.N. 1954. La estructura geológica de la Sierra Pintada (Departamento de San Rafael, provincia de Mendoza). Revista de la Asociación Geológica Argentina 9: 246-252.

Dessanti, R.N. 1956. Descripción geológica de la Hoja 27c-Cerro Diamante (Provincia de Mendoza). Boletín de la Dirección Nacional de Minería 85: 1-79.

Enlow, D.H., and S.O. Brown. 1958. A comparative histological study of fossil and recent bone tissue, part III. The Texas Journal of Science 10: 187-230.

Evans, H.E., and A. deLahunta. 1972. Disección del Perro de Miller (1st edition in Spanish). México: Editorial Interamericana.

Flynn, J.J., D.A. Croft, R. Charrier, G. Hérail, and A.R. Wyss. 2002. The first Cenozoic mammal fauna from the Chilean Altiplano. Journal of Vertebrate Paleontology 22: 200-206.

Forasiepi, A.M., A.G. Martinelli, M. de la Fuente, S. Diéguez, and M. Bond. 2011. Notes on the paleontology and stratigraphy of the Aisol Formation (Neogene, San Rafael, Mendoza Province): New evidences. In Cenozoic Geology of the Central Andes of Argentina, ed. J.A. Salfity, and R.A. Marquillas, 135-154. Salta: Instituto del Cenozoico, Universidad Nacional de Salta.

Forasiepi, A.M., F.J. Goin, and A.G. Martinelli. 2009. Contribution to the knowledge of the Sparassocynidae (Mammalia, Metatheria, Didelphoidea), with comments on the age of the Aisol Formation (Neogene), Mendoza Province, Argentina. Journal of Vertebrate Paleontology 29: 1252-1263.

Francillon-Vieillot, H., V. de Buffrénil, J. Castanet, J. Géraudie, F.J. Meunier, J.Y. Sire, L. Zylberberg, and A. de Ricqlès. 1990. Microstructure and mineralization of vertebrate skeletal tissues. In Skeletal biomineralization: patterns, processes and evolutionary trends, ed. J.G. Carter, 471-755. New York: Van Nostrand Reinhold.

Gabbert, S.L. 2004. The basicranial and posterior cranial anatomy of the families of the Toxodontia. Bulletin of the American Museum of Natural History 285: 177-190.

Garrido, A.C., A. Kramarz, A.M. Forasiepi, and M. Bond. 2012. Estratigrafía, mamíferos fósiles y edad de las secuencias volcano-sedimentarias eoceno-miocenas de la sierra de Huantraico-sierra Negra y cerro Villegas (provincia del Neuquén, Argentina). Andean Geology 39: 482-510.

Goloboff, P.A. 1993. Estimating character weights during tree search. Cladistics 9: 83-91.

Goloboff, P., J.M. Carpenter, S.J. Arias, and D.R. Miranda Esquivel. 2008a. Weighting against homoplasy improves phylogenetic analysis of morphological data sets. Cladistics 24: 1-16.

Goloboff, P., J. Farris, and K. Nixon. 2008b. TNT, a free program for phylogenetic analysis. Cladistics 24: 774-786.

González Díaz, E.F. 1972. Descripción geológica de la Hoja 27d-San Rafael, Provincia de Mendoza. Boletín de la Dirección Nacional de Minería 132: 1-127.

Hurum, J.H., and A. Chinsamy-Turan. 2012. The radiation, bone histology, and biology of early mammals. In Forerunners of mammals: radiation, histology, biology, ed. A. Chinsamy-Turan, 249-270. Bloomington: Indiana University Press.

Jaffey, A.H., K.F. Flynn, L.E. Glendenin, W.C. Bentley, and A.M. Essling. 1971. Precision measurements of half-lives and 
specific activities of ${ }^{235} \mathrm{U}$ and ${ }^{238} \mathrm{U}$. Physical Review $C$ 4: 1889-1906.

Janis, C.M. 1990. Correlation of cranial and dental variables with body size in ungulates and macropodoids. In Body size in mammalian paleobiology: estimation and biological implications, ed. J. Damuth, and B.J. MacFadden, 255-300. Cambridge: Cambridge University Press.

Kay, R.F., R.H. Madden, R.L. Cifelli, and J.J. Flynn. 1997. Vertebrate paleontology in the neotropics. The Miocene fauna of La Venta, Colombia. Washington and London: Smithsonian Institution Press.

Kielan-Jaworowska, Z., R. Presley, and C. Poplin. 1986. The cranial vascular system in taeniolabidoid multituberculate mammals. Philosophical Transactions of the Royal Society of London 313: 525-602.

Kraglievich, L. 1930. La Formación Friaseana del río Frías, río Fénix, Laguna Blanca, etc., y su fauna de mamíferos. Physis 10: $127-161$.

Kramarz, A.G., A. Garrido, A.M. Forasiepi, M. Bond, and C. Tambussi. 2005. Estratigrafía y vertebrados (Aves y Mammalia) de la Formación Cerro Bandera, Mioceno Temprano de la Provincia del Neuquén, Argentina. Revista Geológica de Chile 32: 273-291.

Kramarz, A.G., M. Bond, and A.M. Forasiepi. 2011a. New remains of Astraponotus (Mammalia, Astrapotheria) and considerations on the astrapothere cranial evolution. Paläontologische Zeitschrift 85: $185-200$

Kramarz, A., A.M. Forasiepi, and M. Bond. 2011b. Vertebrados cenozoicos. In Relatorio del XVIII Congreso Geológico Argentino. Geología y Recursos Naturales de la Provincia del Neuquén, ed. H.A. Leanza, C. Arregui, O. Carbone, J.C. Danieli, and J.M. Vallés, 557-572. Neuquén: Asociación Geológica Argentina.

Krogman, W.M. 1930. Studies in growth changes in the skull and face of anthropoids. II. Ectocranial and endocranial suture closure in anthropoids and Old World apes. American Journal of Anatomy 46: $315-353$

López, G.M., M.G. Vucetich, A.A. Carlini, M. Bond, M.E. Pérez, M.R. Ciancio, D.J. Pérez, M. Arnal, and A.I. Olivares. 2011. New Miocene mammal assemblages from Neogene Manantiales basin, Cordillera Frontal, San Juan, Argentina. In Cenozoic Geology of the Central Andes of Argentina, ed. J.A. Salfity, and R.A. Marquillas, 211-226. Salta: Instituto del Cenozoico, Universidad Nacional de Salta.

Lundelius, E.L., V.M. Bryant, R. Mandel, K.J. Thies, and A. Thoms. 2013. The first occurrence of a toxodont (Mammalia, Notoungulata) in the United States. Journal of Vertebrate Paleontology 33: 229-232.

MacPhee, R.D.E. 2014. The serrialis bone, interparietals, " $X$ " elements, entotympanics, and the composition of the notoungulate caudal cranium. Bulletin of the American Museum of Natural History 384: 1-69.

Madden, R.H. 1990. Miocene Toxodontidae (Notoungulata, Mammalia) from Colombia, Ecuador and Chile. Ph.D. thesis, Duke University, North Carolina.

Madden, R.H. 1997. A new toxodontid notoungulate. In Vertebrate Paleontology in the Neotropics: The Miocene Fauna of La Venta, Colombia, ed. R.F. Kay, R.H. Madden, R.L. Cifelli, and J.J. Flynn, 335-354. Washington and London: Smithsonian Institution Press.

Marshall, L.G., and R.L. Cifelli. 1990. Analysis of changing diversity patterns in Cenozoic land mammal age faunas, South America. Palaeovertebrata 19: 169-210.

Marshall, L. G., R. Hoffstetter, and R. Pascual. 1983. Mammals and stratigraphy: geochronology of the continental mammal-bearing Tertiary of South America. Palaeovertebrata, mémoire extraordinaire, 1-93. Montpellier: Laboratoire de paléontologie des vertébrés de l'École pratique des hautes études.

Mattinson, J.M. 2005. Zircon U-Pb chemical abrasion ("CA-TIMS") method: combined annealing and multi-step partial dissolution analysis for improved precision and accuracy of zircon ages. Chemical Geology 220: 47-66.

Mazzoni, M.M. 1986. Procesos y depósitos piroclásticos. Asociación Geológica Argentina. Serie B (Didáctica y Complementaria) 14: $1-115$.

McKenna, M.C. 1975. Toward a phylogenetic classification of mammals. In Phylogeny of the primates, ed. W.P. Luckett, and F.S. Szalay, 21-46. New York: Plenum Press.

Mendoza, M., C.M. Janis, and P. Palmqvist. 2006. Estimating the body mass of extinct ungulates: a study on the use of multiple regression. Journal of Zoology 270: 90-101.

Nassif, N.L., S. Musalem, and E. Cerdeño. 2000. A new toxodont from the late Miocene of Catamarca, Argentina, and a phylogenetic analysis of the Toxodontidae. Journal of Vertebrate Paleontology 20: 591-600.

O’Leary, M.A., J.I. Bloch, J.J. Flynn, T.J. Gaudin, A. Giallombardo, N.P. Giannini, S.L. Goldberg, B.P. Kraatz, Z.X. Luo, J. Meng, X.J. Ni, M.J. Novacek, F.A. Perini, Z.S. Randall, G.W. Rougier, E.J. Sargis, M.T. Silcox, N.B. Simmons, M. Spaulding, P.M. Velazco, M. Weksler, J.R. Wible, and A.L. Cirranello. 2013. The placental mammal ancestor and the post-K-Pg radiation of placentals. Science 339: 662-667.

Owen, R. 1846. Notices of some fossil mammalia of South America. British Association for the Advancement of Science Report 1846, Transactions of the Sections 16: 65-67.

Pascual, R. 1954. Los toxodóntidos del "Colloncurense" descriptos por Roth y su presencia en el Santacruciano. Notas del Museo de la Plata 17: 95-111.

Patterson, B. 1932. On the auditory region of the Toxodontia. Field Museum of Natural History, Geology 6: 1-27.

Patterson, B. 1934. The auditory region of an upper Pliocene typotherid. Field Museum of Natural History, Geology 6: 83-89.

Patterson, B. 1936. The internal structure of the ear in some notoungulates. Fieldiana, Geology 6: 199-227.

Perkins, M.E., J.G. Fleagle, M.T. Heizler, B. Nash, T.M. Bown, A.A. Tauber, and M.T. Dozo. 2012. Tephrochronology of the Miocene Santa Cruz and Pinturas formations, Argentina. In Early Miocene paleobiology in Patagonia: high-latitude paleocommunities of the Santa Cruz formation, ed. S.F. Vizcaíno, R.F. Kay, and M.S. Bargo, 23-40. Cambridge: Cambridge University Press.

Polaco, O.J., A.F. Guzmán, and G. Tapia-Ramírez. 2004. Occurrence of toxodonts in the Pleistocene of México. Current Research in the Pleistocene 21: 113-114.

Rager, L., L. Hautier, A. Forasiepi, A. Goswami, and M.R. SánchezVillagra. 2014. Timing in cranial suture closure in placental mammals: phylogenetic patterns, intraspecific variation, and comparison with marsupials. Journal of Morphology 275: $125-140$.

Rivera, T.A., M. Storey, M.D. Schmitz, and J.L. Crowley. 2013. Age intercalibration of ${ }^{40} \mathrm{Ar} /{ }^{39} \mathrm{Ar}$ sanidine and chemically distinct $\mathrm{U} / \mathrm{Pb}$ zircon populations from the Alder Creek Rhyolite Quaternary geochronology standard. Chemical Geology 345: 87-98.

Roth, S. 1899. Apuntes sobre la geología y la paleontología de los territorios del Río Negro y Neuquén. Revista del Museo de La Plata 9: 143-197.

Roth, S. 1903. Noticias preliminares sobre nuevos mamíferos fósiles del Cretáceo superior y Terciario inferior de la Patagonia. Revista del Museo de La Plata 11: 135-158.

Sánchez Villagra, M.R., O.A. Aguilera, and A.A. Carlini. 2010. Urumaco and Venezuelan Paleontology: the fossil record of the Northern Neotropics. Bloomington: Indiana University Press. 
Schaller, O. 1992. Illustrated veterinary anatomical nomenclature. Stuttgart: Ferdinand Enke Verlag.

Schmidt, G. I. 2013. Litopterna y Notoungulata (Mammalia) de la Formación Ituzaingó (Mioceno tardio-Plioceno) de la Provincia de Entre Ríos: sistemática, bioestratigrafía y paleobiogeografía. Ph.D. thesis, Universidad Nacional de La Plata, La Plata.

Schmitz, M.D., and V.I. Davydov. 2012. Quantitative radiometric and biostratigraphic calibration of the global Pennsylvanian-Early Permian time scale. Geological Society of America Bulletin 124: 549-577.

Schmitz, M.D., and B. Schoene. 2007. Derivation of isotope ratios, errors and error correlations for $\mathrm{U}-\mathrm{Pb}$ geochronology using ${ }^{205} \mathrm{~Pb}-{ }^{235} \mathrm{U}-\left({ }^{233} \mathrm{U}\right)$-spiked isotope dilution thermal ionization mass spectrometric data. Geochemistry, Geophysics, Geosystems 8(8). doi:10.1029/2006GC00149.

Scott, W.B. 1912. Toxodonta. In Reports of the Princeton University expedition to Patagonia, Mammalia of the Santa Cruz beds. Vol. 6, paleontology, part 2, ed. W.B. Scott, 111-238. Princeton: Princeton University.

Sepúlveda, E., A. Bermúdez, O. Bordonaro, and D. Delpino. 2007. Hoja Geológica 3569-IV, Embalse El Nihuil, Provincia de Mendoza. Boletín del Servicio Geológico Minero Argentino, Instituto de Geología y Recursos Minerales 268: 1-52.

Sepúlveda, E., F.W. Carpio, M.C. Regairaz, J.C.M. Zanettini, and M.A. Zárate. 2001. Hoja Geológica 3569-II, San Rafael, Provincia de Mendoza. Boletín del Servicio Geológico Minero Argentino, Instituto de Geología y Recursos Minerales 321: 1-86.

Shockey, B.C., and F. Anaya. 2008. Postcranial osteology of mammals from Salla, Bolivia (late Oligocene): Form, function, and phylogenetic implications. In Mammalian evolutionary morphology: a tribute to Frederick S. Szalay, ed. E.J. Sargis, and M. Dagosto, 135-157. Dordrecht: Springer.
Sláma, J., J. Košler, D.J. Condon, J.L. Crowley, A. Gerdes, J.M. Hanchar, M.S.A. Horstwood, J.A. Morris, L. Nasdala, N. Norberg, U. Schaltegger, B. Schoene, M.N. Tubrett, and M.J. Whitehouse. 2008. Plešovice zircon: a new natural reference material for $\mathrm{U}-\mathrm{Pb}$ and Hf isotopic microanalysis. Chemical Geology 249: 1-35.

Soria, M.F. 1983. Vertebrados fósiles y edad de la Formación Aisol, provincia de Mendoza. Revista de la Asociación Geológica Argentina 38: 299-306.

Straehl, F.R., T.M. Scheyer, A.M. Forasiepi, R.D. MacPhee, and M.R. Sánchez-Villagra. 2013. Evolutionary patterns of bone histology and bone compactness in xenarthran mammal long bones. PLOS ONE 8(7): e69275. doi:10.1371/journal.pone.0069275.

Teruggi, M.E., M.M. Mazzoni, L.A. Spalletti, and R.R. Andreis. 1978. Rocas piroclásticas. Interpretación y sistemática. Asociación Geológica Argentina Serie B (Didáctica y Complementaria) 5: 1-36.

van der Klaauw, C.J. 1931. The auditory bulla in some fossil mammals with a general introduction to this region of the skull. Bulletin of the American Museum of Natural History 62: 1-352.

Vizcaíno, S.F., R.F. Kay, and M.S. Bargo. 2012. Background for a paleoecological study of the Santa Cruz Formation (late Early Miocene) on the Atlantic coast of Patagonia. In Early Miocene Paleobiology in Patagonia: high-latitude paleocommunities of the Santa Cruz Formation, ed. S.F. Vizcaíno, R.F. Kay, and M.S. Bargo, 1-22. Cambridge: Cambridge University Press.

Vucetich, M.G., C.M. Deschamps, C. Morgan, and A.M. Forasiepi. 2011. A new Cardiomyinae (Rodentia, Hydrochoeridae) from western Argentina. Its age and considerations on ontogeny and diversity of the subfamily. Ameghiniana 48: 556-567.

Wible, J.R., and T.J. Gaudin. 2004. On the cranial osteology of the yellow armadillo Euphractus sexcinctus (Dasypodidae, Xenarthra, Placentalia). Annals of Carnegie Museum 73: 117-196. 